\title{
Review \\ Fabrication, Structure, Performance, and Application of Graphene-Based Composite Aerogel
}

\author{
Dequan Wei, Xiang Liu *, Shenghua Lv *, Leipeng Liu, Lei Wu, Zexiong Li and Yonggang Hou
}

check for updates

Citation: Wei, D.; Liu, X.; Lv, S.; Liu,

L.; Wu, L.; Li, Z.; Hou, Y. Fabrication, Structure, Performance, and Application of Graphene-Based Composite Aerogel. Materials 2022, 15, 299. https://doi.org/10.3390/ ma15010299

Academic Editors: Angela Longo, Mariano Palomba and Polina P. Kuzhir

Received: 2 December 2021 Accepted: 29 December 2021 Published: 31 December 2021

Publisher's Note: MDPI stays neutral with regard to jurisdictional claims in published maps and institutional affiliations.

Copyright: (c) 2021 by the authors Licensee MDPI, Basel, Switzerland. This article is an open access article distributed under the terms and conditions of the Creative Commons Attribution (CC BY) license (https:// creativecommons.org/licenses/by/ $4.0 /)$.
College of Bioresources Chemical and Materials Engineering, Shaanxi University of Science and Technology, Xi'an 710021, China; Weidequan@hotmail.com (D.W.); 4233@sust.edu.cn (L.L.); wuleistarry@gmail.com (L.W.); lizexiong0622@sohu.com (Z.L.); houyonggang@sohu.com (Y.H.)

* Correspondence: LiuXiang@sust.edu.cn (X.L.); lvsh@sust.edu.cn (S.L.); Tel.: +86-298-616-8291 (X.L.)

\begin{abstract}
Graphene-based composite aerogel (GCA) refers to a solid porous substance formed by graphene or its derivatives, graphene oxide (GO) and reduced graphene oxide (rGO), with inorganic materials and polymers. Because GCA has super-high adsorption, separation, electrical properties, and sensitivity, it has great potential for application in super-strong adsorption and separation materials, long-life fast-charging batteries, and flexible sensing materials. GCA has become a research hotspot, and many research papers and achievements have emerged in recent years. Therefore, the fabrication, structure, performance, and application prospects of GCA are summarized and discussed in this review. Meanwhile, the existing problems and development trends of GCA are also introduced so that more will know about it and be interested in researching it.
\end{abstract}

Keywords: aerogel; applications; composite; graphene; graphene oxide; inorganic nanoparticle; natural polymer; reduced graphene oxide; structure; synthetic polymer

\section{Introduction}

\subsection{Graphene-Based Composite Aerogel}

Aerogel, a highly porous material with low density and high specific surface area, is obtained by replacing the liquid in wet gel with gas without significantly changing the structure and volume of the gel network. Graphene-based composite aerogel (GCA) is composed of graphene and its derivatives graphene oxide (GO) and reduced GO (rGO) with other matrix materials. Its functions are mainly derived from graphene and its derivatives (graphene-based materials), while its structure and volume stability are mainly determined by other matrix materials [1]. The research results indicate that GCA has lower density, higher porosity, smaller pore diameter, larger specific surface area, and more stable morphology compared to general aerogels, but more importantly it has some unique characteristics, such as higher heat resistance, better electrical conductivity, and higher absorbability of metal ions [2,3]. Therefore, GCA can be used not only as a thermal insulation, sound insulation, damping, and adsorptive material, but also as an electrode material for sensors and energy storage devices [4], which has become a research hotspot and attracted people's attention in recent years. Figure 1 shows the structure, properties, and application of GCA, and Figure 2 displays a structural schematic of graphene-based materials [5]. 


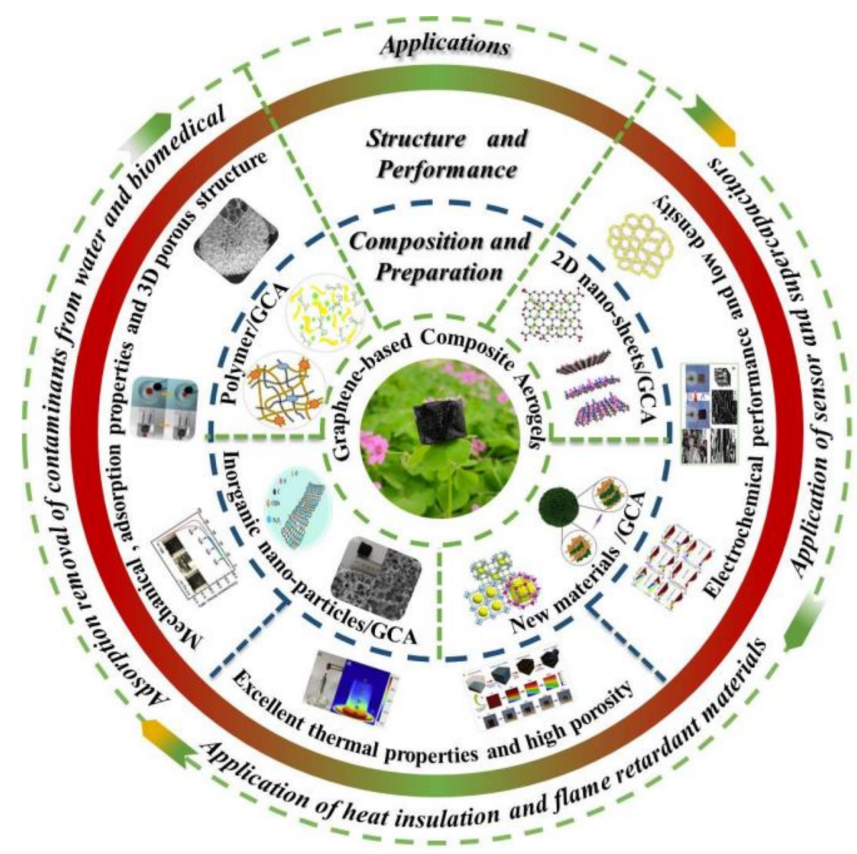

Figure 1. Composition, structure, properties, and applications of GCA.
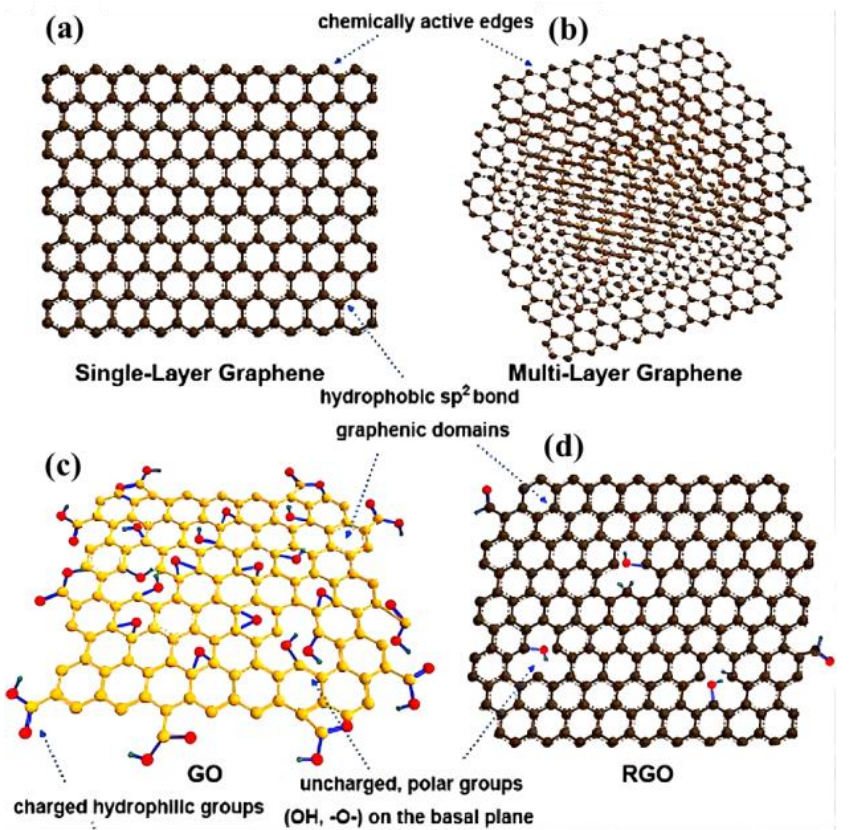

Figure 2. Structural schematic of graphene-based materials: (a) single-layer graphene, (b) multi-layer graphene, (c) GO, (d) rGO [6].

\subsection{Preparation Principle of GCA}

The preparation principle of GCA includes three key processes: sol, gel, and drying. In the sol-gel process, the reactants are uniformly mixed and reacted in the liquid phase to form clusters of different structures. The sol of graphene-based materials and matrix may be obtained by chemical vapor deposition (CVD), hydrothermal reaction, chemical reduction, and vacuum carbonization [7]. Then composite gel is constructed by the self-assembly, chemical cross-linking, template method and 3D printing. The gel contains a large amount of water or other solvents, up to more than $90 \%$, with stable volume and no fluidity [8]. Then the solvent is removed from the gel by freeze-drying or supercritical drying to obtain GCA. The GCA always maintains higher porosity and larger specific surface area and has a 
similar network structure consisting of graphene-based and other matrix materials. Table 1 displays the preparation principle of GCA.

Table 1. Preparation methods and applications of common GCA materials.

\begin{tabular}{|c|c|c|c|}
\hline GCA & $\begin{array}{l}\text { Preparation } \\
\text { Principle }\end{array}$ & Applications & Reference \\
\hline \multirow{3}{*}{ 2D nanosheets/GCA } & $3 \mathrm{D}$ printing & Energy storage materials & [9] \\
\hline & Electrospinning & Wave-absorbing materials & [10] \\
\hline & Self-assembly & Electrocatalysts & [11] \\
\hline \multirow{5}{*}{$\begin{array}{c}\text { Inorganic } \\
\text { nanoparticle } \\
\text { materials/GCA }\end{array}$} & Self-assembly & Wearable piezoresistive sensors & [12] \\
\hline & Sol-gel method & Energy storage material & [13] \\
\hline & Sol-gel method & Gas sensing materials & [14] \\
\hline & CVD & Adsorption materials & [15] \\
\hline & Self-assembly & Catalytic material & [16] \\
\hline \multirow{4}{*}{$\begin{array}{c}\text { Synthetic } \\
\text { polymer/GCA }\end{array}$} & Sol-gel method & Pressure response sensor & [17] \\
\hline & Template method & Thermal insulation materials & [18] \\
\hline & Immersion method & Porous electrode & [19] \\
\hline & Self-assembly & Energy storage material & {$[20]$} \\
\hline \multirow{5}{*}{$\begin{array}{c}\text { Natural } \\
\text { polymer/GCA }\end{array}$} & CVD & Adsorption materials & [21] \\
\hline & Template method & Thermal insulation materials & [22] \\
\hline & Self-assembly & Supercapacitor materials & [23] \\
\hline & Sol-gel method & Adsorption materials & [24] \\
\hline & $\begin{array}{c}\text { Chemical } \\
\text { cross-linking }\end{array}$ & Adsorption materials & [25] \\
\hline
\end{tabular}

\subsection{Current Research Situation}

Figure 3 shows the number of papers published on GCA from 2010 to 2021, indicating that the research began in 2010 and the number of papers grew exponentially in the last 10 years. According to the literature reports, GCA is usually composed of graphene and its derivatives and matrix materials. The properties and functions of GCA are mainly determined by graphene and its derivatives, while the porous structure and stability are mainly determined by matrix materials. The matrix materials include inorganic nanomaterials, synthetic polymers and natural polymers. Therefore, the research process on the fabrication method, material selection, structure construction, performance and application design of GCA is very complex, and it is necessary to summarize and guide based on these research results. Currently there is also a lack of targeted summary articles. In this review, we focus primarily on reviewing the fabrication of GCA with inorganic nanomaterials, synthetic polymer, and natural polymers along with its structure, performance, and applications. 


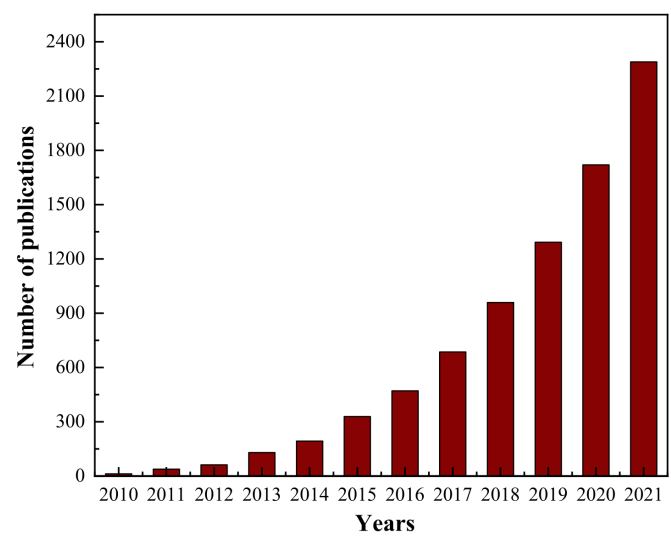

Figure 3. Number of papers on GCA in the last 12 years (as of 20 September 2021 by Science Direct record).

\section{Composition of GCA}

GCA usually consists of graphene-based materials and inorganic 2D nanosheets materials, inorganic nanoparticle materials, synthetic polymers, and natural polymers.

\section{1. $2 D$ Nanosheets/GCA}

Inorganic 2D nanosheet materials can be compounded with graphene-based materials to prepare aerogels with better properties, including $\mathrm{Ti}_{3} \mathrm{C}_{2} \mathrm{~T}_{\mathrm{x}}$ (MXenes), transition metal sulfide (TMD), metal organic framework (MOF), hexagonal boron nitride (h-BN), layered double hydroxide (LDH), perovskite and black phosphorus (BP), and other hot materials [26].

Mxenes is a kind of flexible 2D nanosheet with light weight, high electrical conductivity, high surface activity, and excellent electrochemical properties. Li et al. [10] prepared GCA by forming MXenes@GO composites by electrospinning, and the GCA as a waveabsorbing material had the advantages of light weight and elongated attenuating paths. The preparation process and mechanism are shown in Figure 4. 2D MoS 2 nanowires were fixed on the $2 \mathrm{D}$ rGO nanowires by 3D printing technology, which could solve the disadvantage of low conductivity of $\mathrm{MoS}_{2}$ and prepare GCA for sodium ion batteries. [9] The introduction of 2D nanomaterials in GCA has aroused widespread interest, but reasonable design steps are needed to achieve superior properties of GCA, including the need to consider the problem of easy agglomeration in the composite process.

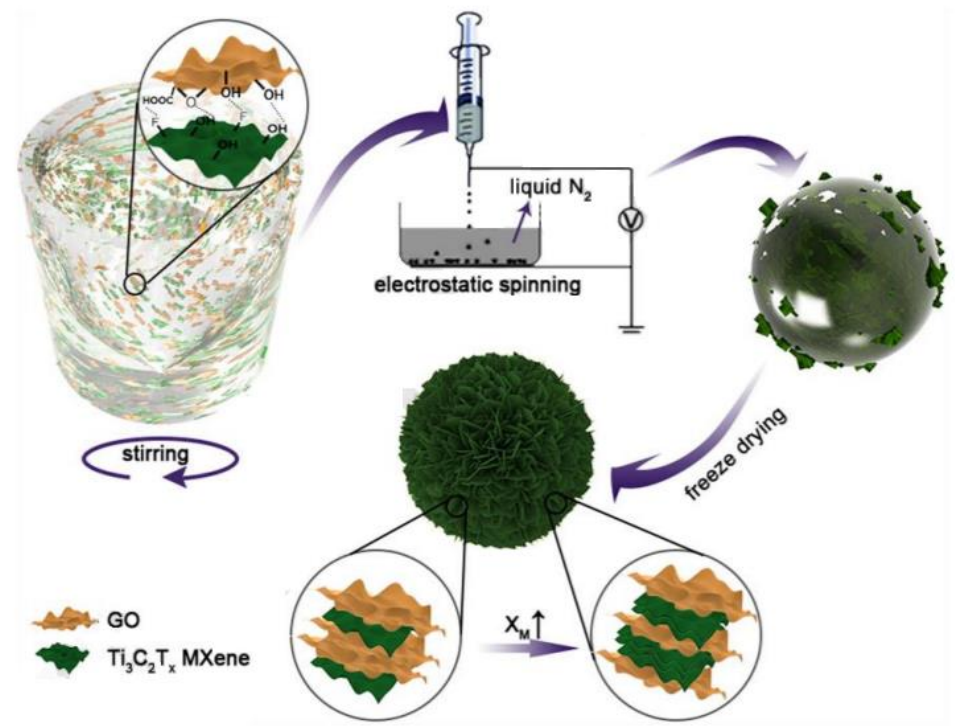

Figure 4. Assembly mechanism of MXenes@GO composite aerogel [10]. 


\subsection{Inorganic Nanoparticle Materials/GCA}

Inorganic nanoparticles, such as $\mathrm{SnO}_{2}, \mathrm{SiO}_{2}, \mathrm{TiO}_{2}, \mathrm{IO}$, etc. [27], have been widely used to prepare GCA. Nanoparticle GCA can be prepared by surface modification of inorganic nanoparticles or as a composite with graphene and hydrothermal assembly [28]. Cheng et al. [13] reported that $\mathrm{TiO}_{2} / \mathrm{GCA}$ prepared by template-free method had excellent electrochemical properties and could be used as lithium battery anodes and highperformance energy storage. In addition, the solvothermal method of depositing $\mathrm{ZnO}$ nanoparticles on graphene nanosheets to prepare ZnO/GCA (Figure 5) showed good thermal conductivity performance, a porous network structure, and high specific surface area, and had greatly increased contact with gas, and these characteristics make ZnO/GCA suitable for preparing gas-sensing materials [14]. IO/GCA was prepared by the in situ growth method in a high-gravity reactor, with good catalytic efficiency for catalyzing the photo-Fenton reaction [16]. Graphene, combined with the good electronic, optical, and thermal conductivity of inorganic nanoparticles for preparing aerogels, broadens its potential applications in batteries, catalysis, sensors, and so on.
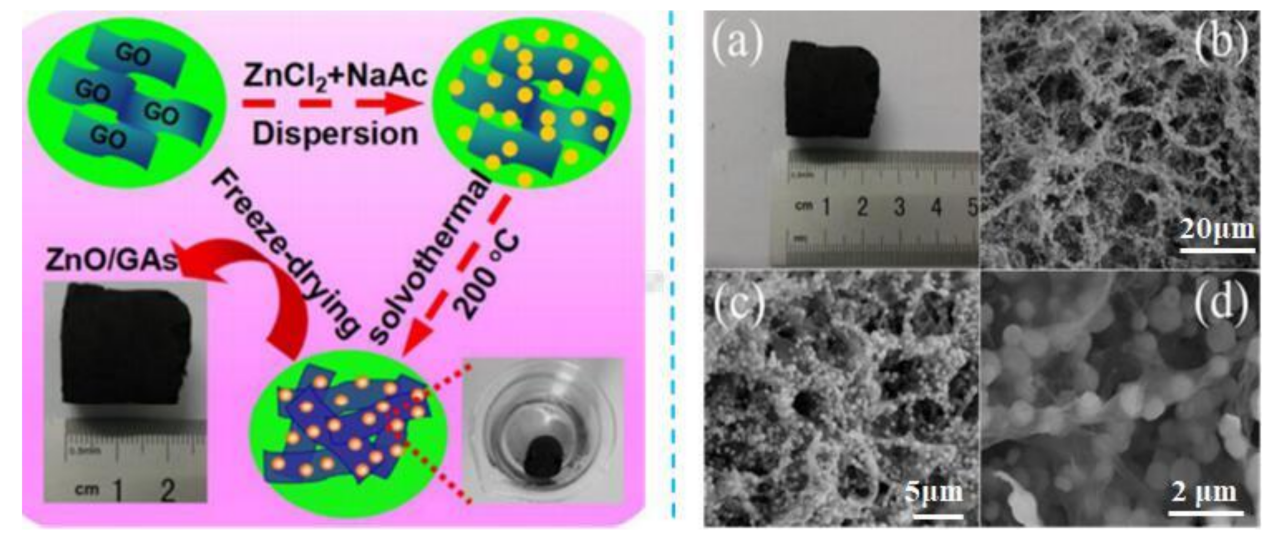

Figure 5. Preparation process of ZnO/GCA: (a) Macro-morphology and (b-d) Micro-morphology by SEM [14].

\subsection{Synthetic Polymer/GCA}

The weak strength of pure graphene aerogels greatly limits their practical application. However, this situation can be changed by forming composite GCA with some synthetic polymers, such as PE, PVA, PDMS, PANI, PAM, PM. Synthetic polymer/GCA has higher strength, lower density, larger specific surface area, and good strength and electrochemical properties, and can make sensors, adsorbents, catalysts, and other items [29]. As shown in Figure 6, Xiang et al. [17] prepared PVA/GCA by using $\gamma$-oxo-1-pyranobutyric acid (OPBA) as adhesive to hold the PVA coating and graphene skeleton together. The GCA can be used as a pressure response sensor due to its compressibility and deformation recovery. Zhang et al. [18] produced PDMS/GCA aerogel by permeation of PDMS into the interior of graphene aerogel to obtain aerogel with ultra-high electrical conductivity $\left(1 \mathrm{~S} \cdot \mathrm{cm}^{-1}\right)$, thermal conductivity $\left(0.58 \mathrm{~W} \cdot \mathrm{m}^{-1} \cdot \mathrm{K}^{-1}\right)$, high hydrophobicity (contact angle $135^{\circ}$ ), and excellent strength and thermal stability. An et al. [19] deposited polyaniline (PANI) into porous graphene microspheres to make conductive spherical PANI/GCA, and the inclusion of PANI enhanced the graphene network and made the microspheres more resistant to deformation (Figure 7), which had the characteristics of shrinkage after water loss, recovery after dissolution, high specific capacitance, and good cycle stability, so they can be used as porous electrodes for energy conversion. 


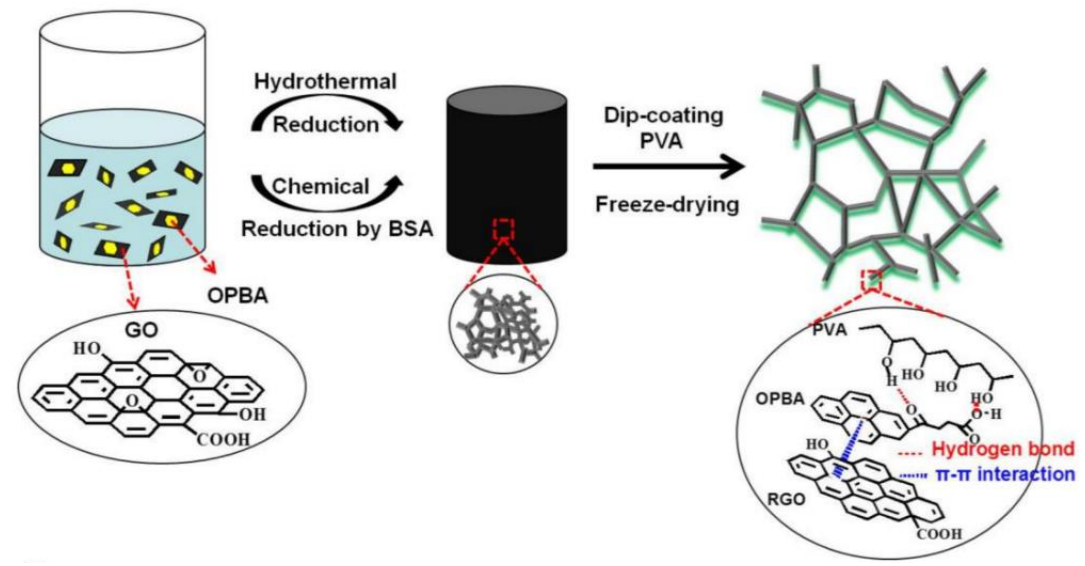

Figure 6. Schematic diagram of preparation process of PVA/GCA [17].

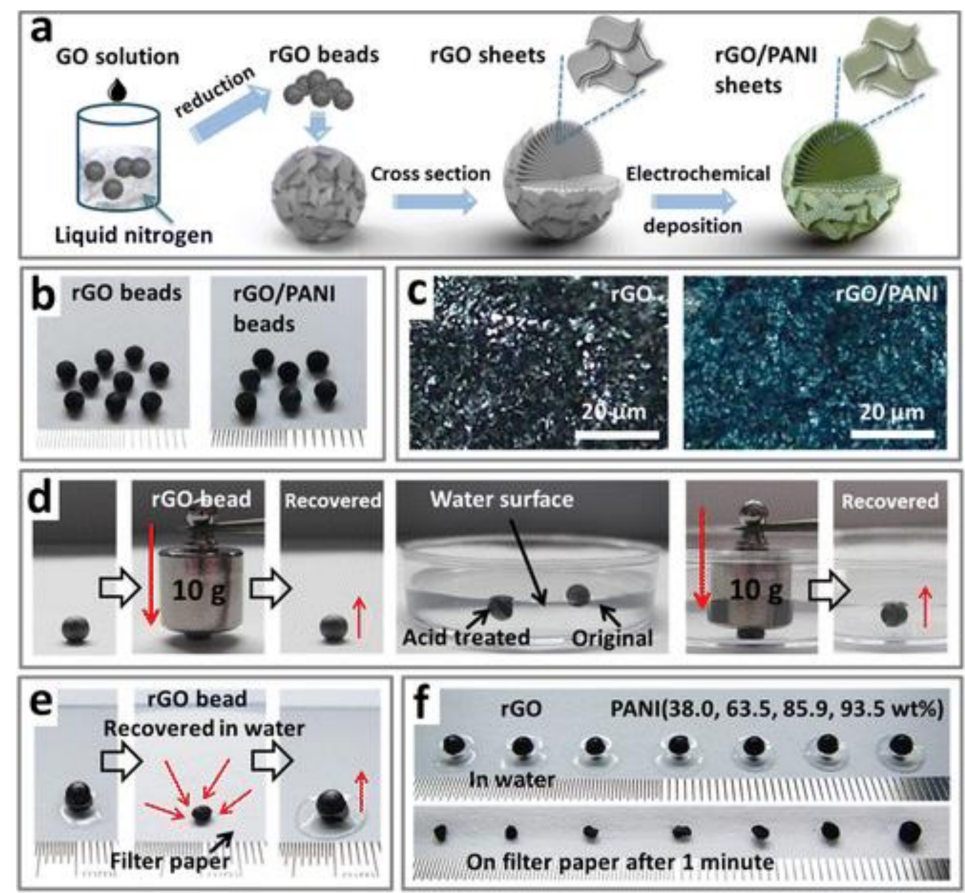

Figure 7. Schematic diagram of preparation of PANI/GCA: (a) Freeze-casting to prepare PANI/rGO aerogels; (b) PANI/rGO aerogel samples; (c) Microstructure of PANI/rGO aerogels; (d) Preparing rGO aerogels; (e) Recovery of shrunken rGO aerogels in water; (f) Shrinkage degree of GO and $\mathrm{PANI} / \mathrm{rGO}$ aerogel by loss of water [19].

In short, the disadvantage of a weak structure in the reapplication of 3D graphene can be solved by preparing synthetic polymer modified GCA in various shapes, such as sol-gel, immersion, hydrothermal reaction, or chemical weather deposition. With better strength, adsorption, and electrical properties, the new synthetic polymer/GCA has great development prospects. Therefore, in the future, new forms of synthetic polymer/GCA should be developed by seeking new synthetic polymers and preparation methods for better performance.

\subsection{Natural Polymer/GCA}

The natural polymers mainly include cellulose, starch, chitosan, sodium alginate, carrageenan, and pectin. Aerogels of natural polymers have abundant resource advantages, good biocompatibility and biodegradability, and can be exploited in medicine, environmental engineering, and food packaging [30]. The introduction of graphene-based materials 
not only improves the shortcomings of low mechanical strength, poor brittleness, and poor stability of natural polymeric aerogels, but affects their structure and properties.

\subsubsection{Cellulose/GCA}

Cellulose is the most abundant natural polymer in nature [31]; it is divided into cellulose nanocrystal (CNC), [32] cellulose nanofiber (CNF), and bacterial cellulose (BC) according to the formation conditions and sources [33].

Cellulose/GCA can be prepared by a self-assembly process [34], and the formation mechanism is shown in Figure 8. Mi et al. [21] obtained cellulose/GCA by bi-directional freezing and CVD (Figure 8). This composite aerogel presented a porous structure with ultra-low density $\left(0.0059 \mathrm{mg} \cdot \mathrm{cm}^{-3}\right)$ and high surface area $\left(47.3 \mathrm{~m}^{2} \cdot \mathrm{g}^{-1}\right)$, and had good selective adsorption effect for oil. Using boric acid (BA) as cross-linker of GO and carboxymethyl cellulose (CMC), Ge et al. [22] synthesized CMC/GCA by the ice template method (Figure 9). The results showed that the GO content had a significant influence on the morphology and strength of the aerogel. When the content of GO reached $5 \mathrm{wt} \%$, the strength was excellent, and thermal conductivity $\left(0.0417 \mathrm{~W} \cdot \mathrm{m}^{-1} \cdot \mathrm{K}^{-1}\right)$ was similar to that of polystyrene foam $\left(0.03-0.04 \mathrm{~W} \cdot \mathrm{m}^{-1} \cdot \mathrm{K}^{-1}\right)$. There is a good interaction between cellulose and GCA with the 3D structure, which provides a way to improve the mechanical properties of aerogels. The self-assembly process, CVD method, and template method can introduce cellulose into graphene to produce aerogels with better mechanical properties, thermal insulation, and energy storage.

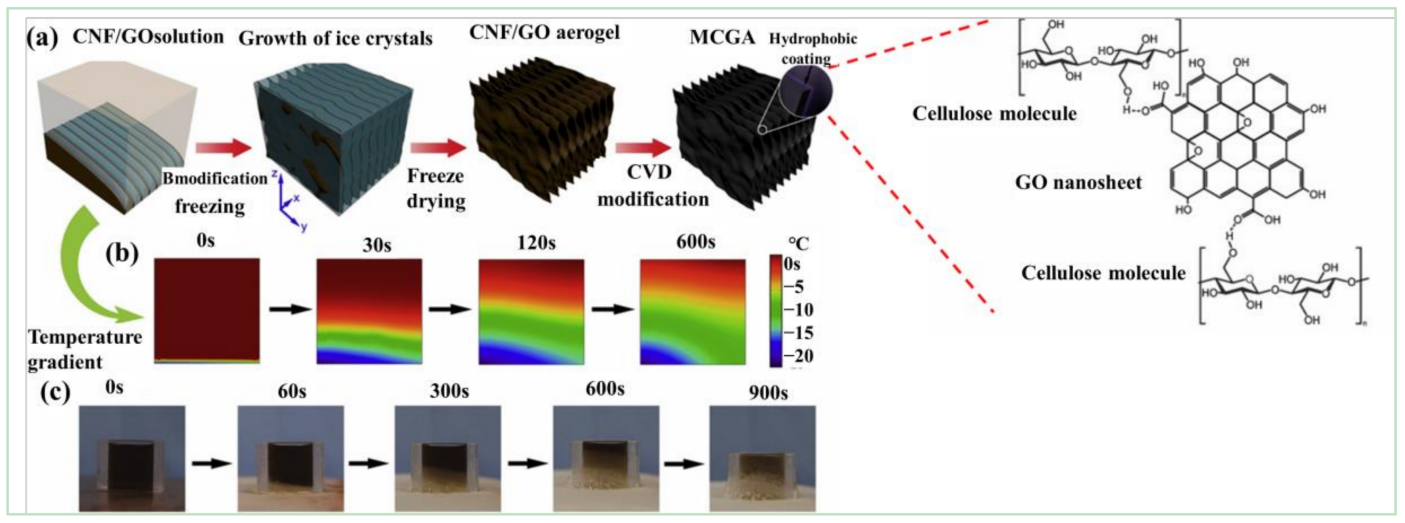

Figure 8. Schematic of hydrogen bond interactions between GCA and cellulose [34]: (a) Bi-directional freeze-drying preparation of cellulose/GCA; (b) Temperature gradient simulation in the freezing process; (c) Digital image of solution freezing process of two-way freezing [21].

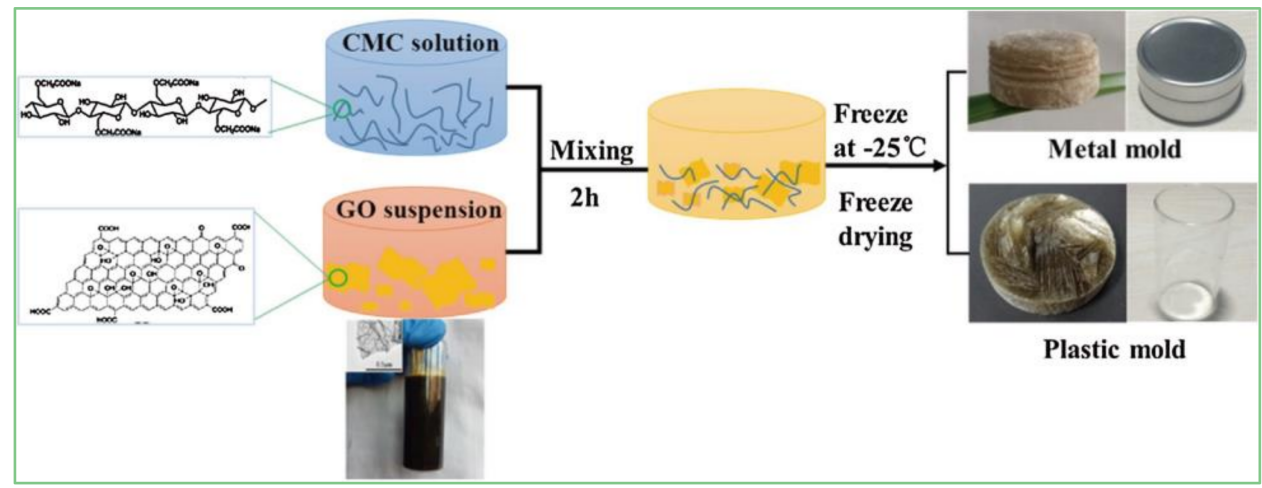

Figure 9. Schematic demonstration of CMC/GCA composite aerogel preparation [22].

\subsubsection{Starch/GCA}

Starch is one of the most common biopolymers and usually divided into amylose and amylopectin according to the chemical structure. Starch in its natural form can eas- 
ily form a gel without a cross-linking agent [35]. Chen et al. [23] developed a simple and rapid method for preparing porous starch/GCA. The aerogels can be used as electrode materials to manufacture flexible and gel-type symmetrical supercapacitors with excellent capacitance performance and high energy density (Figure 10). Starch/GCA was prepared by chemical reduction and self-assembly of nanocrystalline starch, which has higher mechanical properties, capacitance performance, and adsorption capacity.

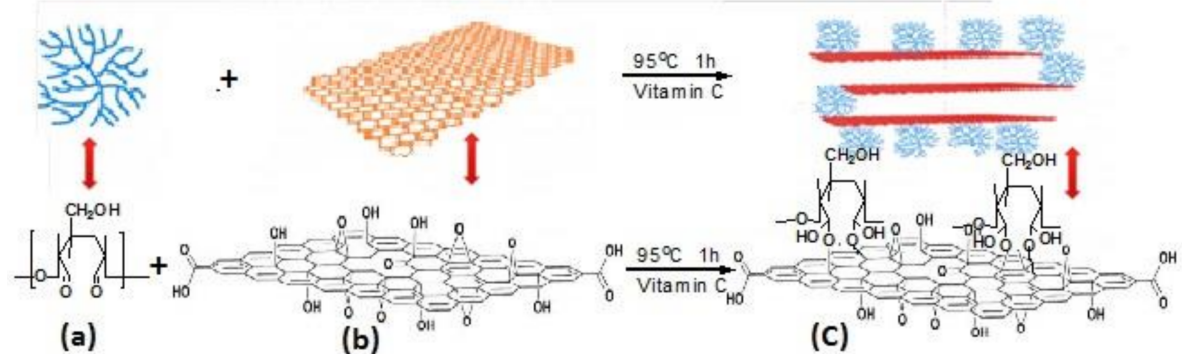

Figure 10. Fabrication and structure of starch/GCA [23]. (a) Starch; (b) Graphene oxide; (c) Starch/GCA.

\subsubsection{Chitosan/GCA}

Chitosan (CS) is extracted and processed from the shells of common arthropods [36]. The aerogel prepared by CS can be exploited as an adsorbent for sewage purification, but its strength is poor. Therefore, it must be modified to increase its strength. Interestingly, the introduction of graphene-based materials can improve not only the strength and stability of the CS aerogel, but also the purification efficiency and degree. Using solution mixing and injection methods, CS/GCA of various shapes can be prepared and applied in many fields [37], such as CS/GCA microspheres and membranes (Figure 11) [38]. In addition, both graphene and CS are used as the basic skeleton or filling material of GCA, which significantly improve the aerogel's properties. When CS was grafted onto a GO skeleton, the GCA with more ordered mesoporous and the adsorption capacity was significantly superior to that of pure CS aerogel [24]. CS/GCA has enough strength and stability and excellent absorbability for heavy metals, dyes, and organic solvents. Therefore, CS/GCA will still be a hot spot of research and application in the future.

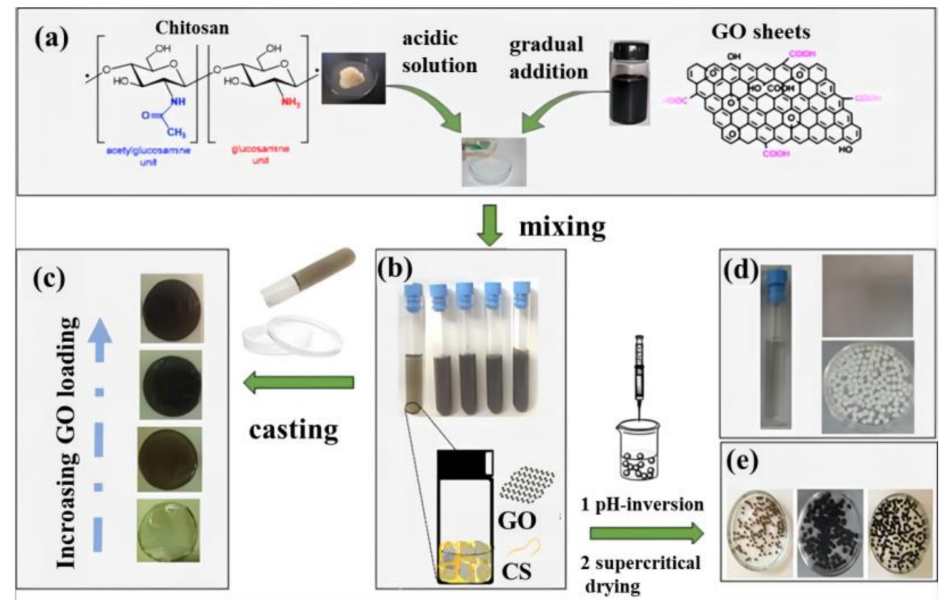

Figure 11. Schematic diagram of preparation process of CS/GCA [38]. (a) Chemical structure of chitosan and graphene oxide as two mixed dissimilar phases; (b) Digital photo of CS-GO acidicaqueous solution with increasing GO weight percentage; (c) The as-prepared hybrid films (denoted as CS-GO) with increasing GO amount; (d) Self-standing chitosan-graphene oxide aerogel microspheres with increasing amount of GO in the mixture; (e) Blank materials prepared for comparison: chitosan aqueous acidic solution, chitosan film and chitosan microspheres. 


\subsubsection{Sodium Alginate/GCA}

Sodium alginate (SA), an anionic polysaccharide with hydroxyl and carboxyl groups, comes from algae. It is widely used in medical stents, controlled-release drug carriers, and food thickeners, and also as a flocculant for treating wastewater. SA has different solubility affected by $\mathrm{pH}$ value. When the $\mathrm{pH}$ is less than 4 , SA is insoluble, and when the $\mathrm{pH}$ is between 6 and 9, SA is a viscous solution. Although it is easy to form film and gel, SA-polysaccharide aerogel has weak strength and stability. Therefore, many studies have focused on functional modification and composite hybridization to overcome the limitations of the aerogel.

SA can be physically blended with graphene and chemically modified to improve its strength compared to the brittleness and easy collapse of pure SA aerogel (Figure 12) [31]. Shan et al. [25] applied in situ cross-linking to prepare SA/GCA, and the introduction of GO improved the uniformity of the spherical morphology and the efficiency and capacity of phosphorus ion adsorption in sewage, and was applied to remove phosphine pollution in water. In particular, the introduction of graphene can increase electrical conductivity and broaden the application of SA aerogel to other fields, such as its use as electrode material for supercapacitors and as a biomass aerogel catalyst with good catalytic activity.

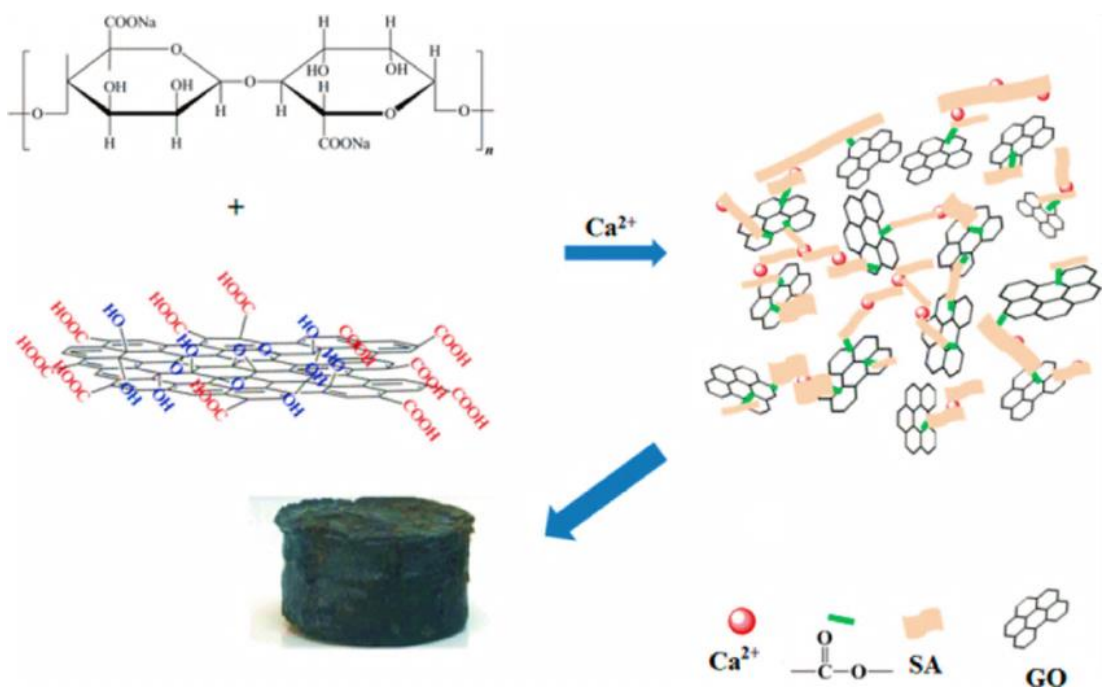

Figure 12. Synthesis route of SA/GO composite aerogel [39].

\section{Structure of GCA}

\subsection{Porous Structure of GCA}

GCA has a porous network structure and low density. Pore structure is closely related to strength, thermal performance, and electrochemical performance. In addition, GCA can uniformly disperse the graphene nanolayers in the matrix in the form of a single layer or a few layers to reduce agglomeration. Different pore diameters of aerogels also affect their density, pore volume, and specific surface area. For example, pore volume is the volume of pores per unit mass of aerogel and is related to the inner and outer diameter. With the same inner diameter, the pore volume decreases along with the increase of the outer diameter, and with the same outer diameter, the larger the inner diameter, the larger the pore volume. Like specific surface area, pore volume is another important factor affecting the surface adsorption and loading properties of aerogels. The structural parameters, including specific surface area, density, and pore size of GCA, are listed in Table 2. 
Table 2. Fabrication methods and morphology of GCA materials.

\begin{tabular}{|c|c|c|c|c|c|c|}
\hline $\begin{array}{c}\text { Composite } \\
\text { Aerogel } \\
\text { Material }\end{array}$ & $\begin{array}{c}\text { Fabrication } \\
\text { Method }\end{array}$ & $\begin{array}{c}\text { Specific } \\
\text { Surface Area } \\
\left(\mathrm{m}^{2} \cdot \mathrm{g}^{-1}\right)\end{array}$ & $\begin{array}{c}\text { Density } \\
\left(\mathrm{mg} \cdot \mathrm{cm}^{-3}\right)\end{array}$ & $\begin{array}{l}\text { Pore } \\
\text { Volume } \\
\left(\mathrm{cm}^{3} \cdot \mathrm{g}^{-1}\right)\end{array}$ & $\begin{array}{l}\text { Diameter } \\
(\mathrm{nm})\end{array}$ & Reference \\
\hline GNPA & Self-assembly & / & 59.3 & / & 5 & [12] \\
\hline $\mathrm{GO} / \mathrm{SiO}_{2}$ & Sol-gel method & 889 & / & 3.72 & 16.75 & [40] \\
\hline $\mathrm{VO}_{2} / \mathrm{GA} @ \mathrm{NiS}_{2}$ & Sol-gel method & 141.1 & / & / & 17.3 & [41] \\
\hline Co-N-GA & Self-assembly & 485 & 0.29 & 0.71 & / & [11] \\
\hline PPy@GA & Self-assembly & 686 & 7.8 & / & / & [20] \\
\hline MGGNA & Freeze-drying & 45.1 & 2.32 & / & / & [42] \\
\hline GNR & Self-assembly & 113.1 & 9.33 & / & / & [43] \\
\hline $\mathrm{MoS}_{2}-\mathrm{RGO}$ & 3D printing & / & / & / & $100-200$ & [9] \\
\hline 3D-GMOs & CVD & 560 & 22 & / & / & [15] \\
\hline N-CMS/GA & Mixed & 450 & / & / & $3.4-36.9$ & [44] \\
\hline
\end{tabular}

GNPA, graphene-PVA-co-PE nanofiber-PVA aerogel; Co-N-GA, hierarchically porous Co-N functionalized graphene aerogel; PPy@GA, poly-pyrrole nanosphere graphene aerogel; MGGNA, capillary-like hydrophobic GO/GONR-APTES composite aerogel; GNR, graphene nanoribbon aerogel; 3D-GMOs, high-density threedimensional GA macroscopic objects; N-CMS/GA, nitrogen-doped carbon microsphere/graphene aerogel.

In terms of the morphology of aerogels, GCA can be roughly divided into two categories: porous structure and mesoporous core-shell structure. The common porous structures include honeycomb, microsphere, etc. The local compressibility and elasticity of aerogel honeycomb structure were well studied by density functional theory (DFT) [45]. The honeycomb structure [46] has the characteristics of ultra-low density, super-elasticity, good electrical conductivity, and high energy absorption efficiency (Figure 13), which is related to its inherent mechanical properties and elasticity [47]. By adjusting the method and process parameters, optimizing a complete honeycomb structure can control the specific surface area, density, pore size, appearance, and other morphological characteristics of GCA, and further change its mechanical and thermal properties and electrical conductivity.
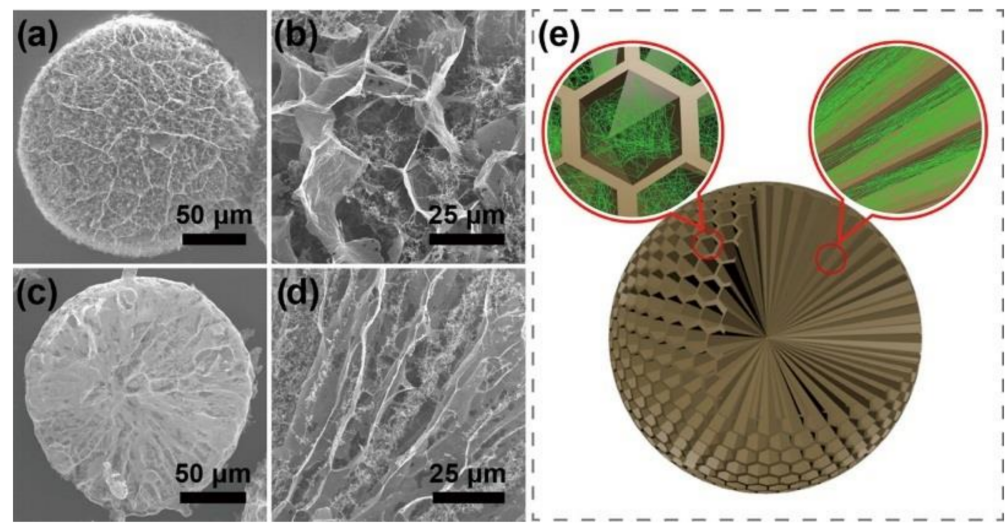

Figure 13. SEM images of: (a,b) Graphene aerogel, (c,d) GCA, and (e) Microchannel structures of GCA [47].

\subsection{Mesoporous Core-Shell Structure of GCA}

Microspheres with mesoporous and core-shell structure produced by GCA exhibit greater strength and have wider application. These aerogels can usually be obtained using the sol-gel, blending, or other method to obtain hydrogels, which are then transformed into aerogel by freeze-drying or super-zero boundary $\mathrm{CO}_{2}$ drying. Liu et al. [48] prepared GCA with well-shaped microspheres and with internal honeycomb, which could be exploited as a photocatalyst and adsorbent. As shown in Figure 14, the shape of the honeycomb and the mesoporous microspheres with an internal radial microchannel structure help in shortening the diffusion path of pollutants and promoting a rapid adsorption equilibrium in the treatment of sewage. Therefore, the relationship between the design of the honeycomb structure and the performance and application of GCA needs further study. 


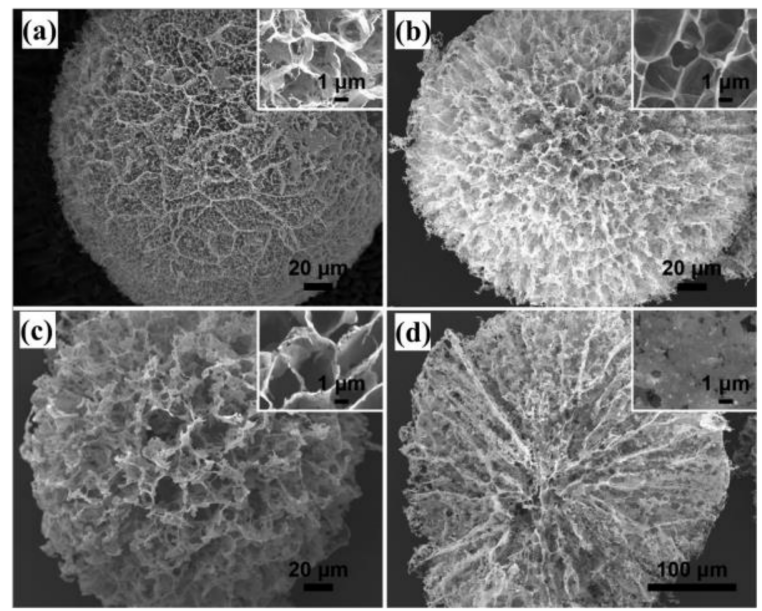

Figure 14. SEM images of: (a) GCA, (b) GCA1 (50\% $\left.\mathrm{Ag}_{3} \mathrm{PO}_{4}\right)$; (c) GCA3 (75\% $\mathrm{Ag}_{3} \mathrm{PO}_{4}$ ); (d) Crosssection of GCA microspheres [48].

Compared with the mesoporous microspheres structure, the core-shell structure is more complicated. Researchers have adjusted the pore structure of GCA aerogels by controlling the freezing temperature and direction of ice crystals formed between graphene layers. In addition, in order to form dense nuclei and sparse filling shells, the freezing temperature gradient is needed to control the nucleation and growth of ice crystals to obtain GCA microspheres with core-shell structure (Figure 15). This unique structure achieves high compressive strength by continuously distributing mechanical loads between core and shell, resulting in improved mechanical, electrical, and thermodynamic properties.

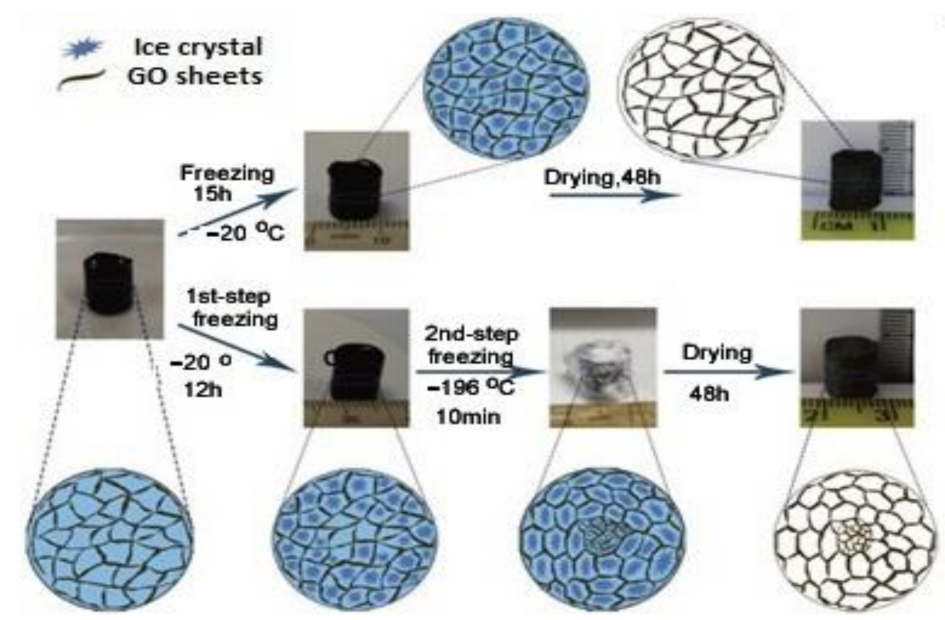

Figure 15. Schematic illustration of fabrication of GCA microspheres with core-shell structure [49].

\subsection{Methods for Adjusting the Porous Structure of GCA}

The pore structure of GCA can be adjusted by controlling the concentration of polymers, inorganic nanomaterials, and graphene nanosheets. The template effects and selfassembly process of graphene-based materials can be used to change the pore structure of aerogels and other materials [50]. In addition, the newly developed impregnation method and 3D printing technology have better effects on regulating the pore structure. Compared with traditional strategies, they greatly broaden the unique functional structure with controllable structural parameters [51]. 


\section{Properties of GCA}

\subsection{Adsorptive Properties}

Adsorption properties include physical and chemical adsorption. GCA aerogel's abilities are connected with the structural design and performance of the material. In terms of structural design, 3D GCA usually has a larger specific surface area, higher porosity, and an interconnected porous structure, which can increase its combination with other functional materials and promote the diffusion of ions and molecules [52]. In addition, magnetic inorganic nano-GCA $\left(\mathrm{Co}_{3} \mathrm{O}_{4}, \mathrm{Fe}_{3} \mathrm{O}_{4}\right)$ is easy to recycle [53]. Introducing different functional groups, such as amino and phosphate groups, into 3D GCA leads to different adsorption mechanisms, such as ion exchange, complexation, chelation, electrostatic interaction, hydrogen bond, $\pi-\pi$, hydrophobic interaction, etc. [54].

The adsorption of metal ions requires a large number of oxygen-containing functional groups $(-\mathrm{OH},-\mathrm{COOH},-\mathrm{O}-)$ on the $\mathrm{GO}$ surface combined with positively charged heavy metal ions through electrostatic interactions, or surface complexes to form metal complexes [55]. At the same time, a porous network structure effectively prevents the accumulation of GO, promotes the free diffusion of heavy metal ions, and broadens the contact probability of heavy metal ions with an active center. Additionally, $\pi-\pi$ interactions and hydrogen bonds were observed between the edges of graphene [56], which efficiently bound and adsorbed dye molecules and metal ions (Figure 16) [47].

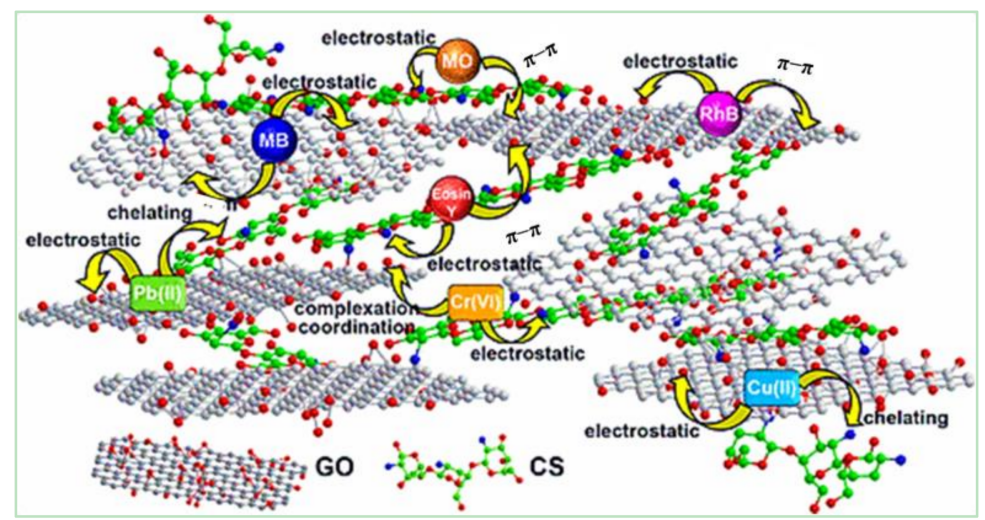

Figure 16. Schematic diagram of purification mechanisms of CS/GO aerogels for sewage [47].

Furthermore, after the design and construction of roughness, the introduction of hydrophobic groups, and the thermal annealing reduction process, GCA was shown to have hydrophobic and lipophilic adsorption properties, which benefited oil-water separation [57]. Using the unique 3D porous structure, hydrogen bonds, and $\pi-\pi$ interaction characteristics also adsorbed antibiotics and other drugs. These adsorption characteristics make it valuable for application in sewage purification.

\subsection{Mechanical Properties}

The key mechanical properties of GCA include compressive strength and deformation resistance. However, pure graphene aerogel is too weak for practical use. For this reason, various cross-linking agents or structural enhancers are introduced to prepare GCA with high elasticity and mechanical properties [58]. For example, some 2D materials were used as structural reinforcement materials for GCA, such as MXenes, which helped the aerogel obtain a super-elastic structure [59]. Organic nanomaterials, synthetic polymers, and natural polymers are commonly used as mechanical reinforcements for GCA to maximize its mechanical performance [60].

As shown in Figure 17, cross-linking agents or structural strengthening materials improved the mechanical stability and the relationship between microstructure anisotropy and mechanical strength of the transverse (TD) and longitudinal (LD) direction of composite aerogels; compared with pure graphene, the maximum compressive strength of LD and 
TD was increased by more than 10 times $(10-50 \mathrm{kPa})$ [61]. Therefore, reasonable design of the preparation process is very important in order to improve the mechanical properties of composite aerogels without adversely affecting other functional performance.

Compression along longitudinal direction(LD) and transverse direction(TD) of thecylindrical aerogel

(a)

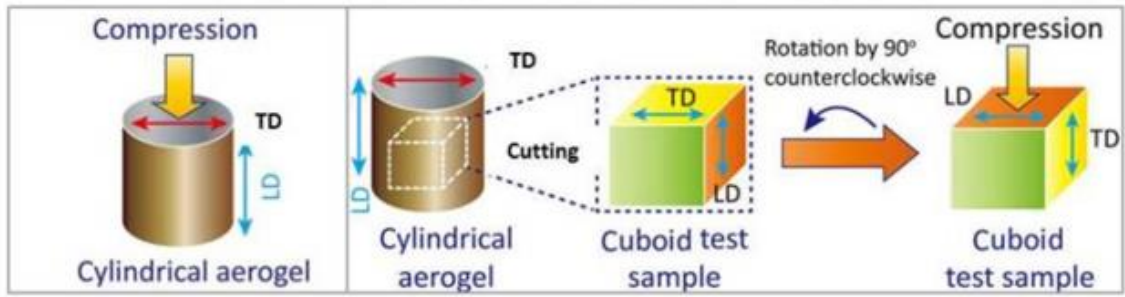

(b)

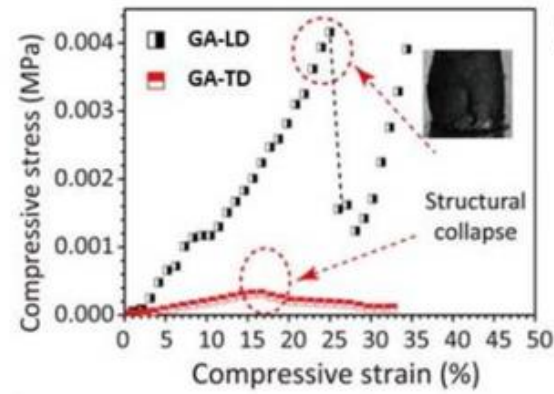

(d)

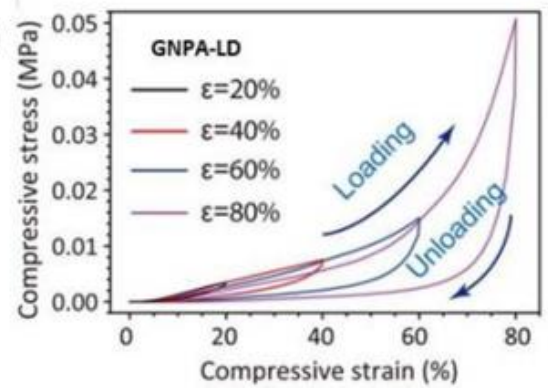

(c)

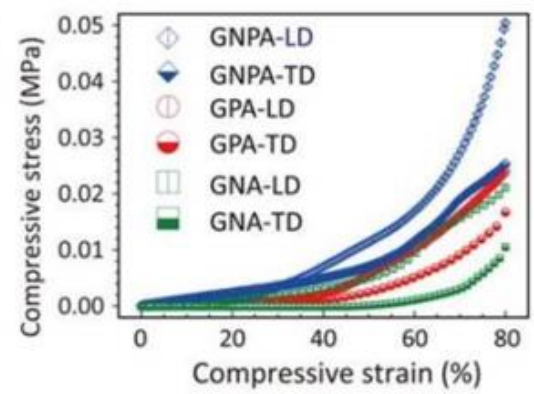

(e)

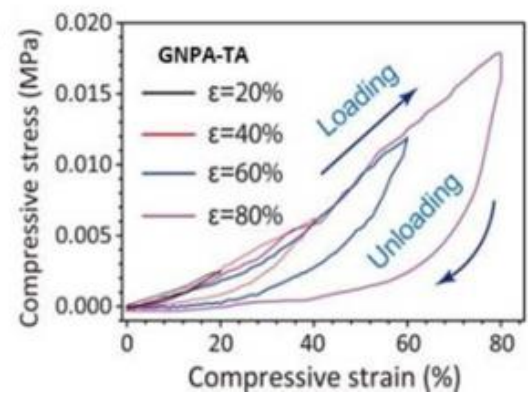

Figure 17. (a) Schematic of sampling instructions for expression test along TD and LD; (b,c) Stressstrain surveys of all testing samples in LD and TD; (d,e) Loading-unloading stress-strain surveys for GCA-LD and GCA-TD under different strains [61].

\subsection{Thermal Properties}

The thermal conductivity of graphene is $5000 \mathrm{~W} \cdot \mathrm{m}^{-1} \cdot \mathrm{K}^{-1}$, which makes it a suitable filler for the preparation of composites, with excellent thermal properties [62]. The inherent characteristics of aerogels, such as light weight and very low thermal conductivity, provide new ideas for the development of heat insulation materials. However, the distribution of graphene nanosheets, the density of aerogel, and the pore structure of GCA affect its thermal properties; for example, uniformly distributed graphene nanosheets can greatly reduce or eliminate the contact thermal resistance and thus improve the thermal conductivity, whereas the low bulk density of the aerogel decreases thermal conductivity [63]. Therefore, in order to design materials with better thermal properties, the advantages of both need to be taken into account. For example, Wang et al. [64] prepared layered porous and continuous silk fibroin SF/GCA fibers by wet-spinning and freeze-drying, showed that the introduction of GO not only improved the mechanical properties, but also significantly raised the thermal properties under infrared radiation. Compared with pure SF aerogel fibers, the surface temperature of the SF/GCA was increased by $2.6^{\circ} \mathrm{C}$ after infrared radiation for $30 \mathrm{~s}$. At the same time, layered porous and hollow fiber structures reduced heat conduction and inhibited thermal radiation, providing good thermal insulation of SF/GCA fibers (Figure 18). 


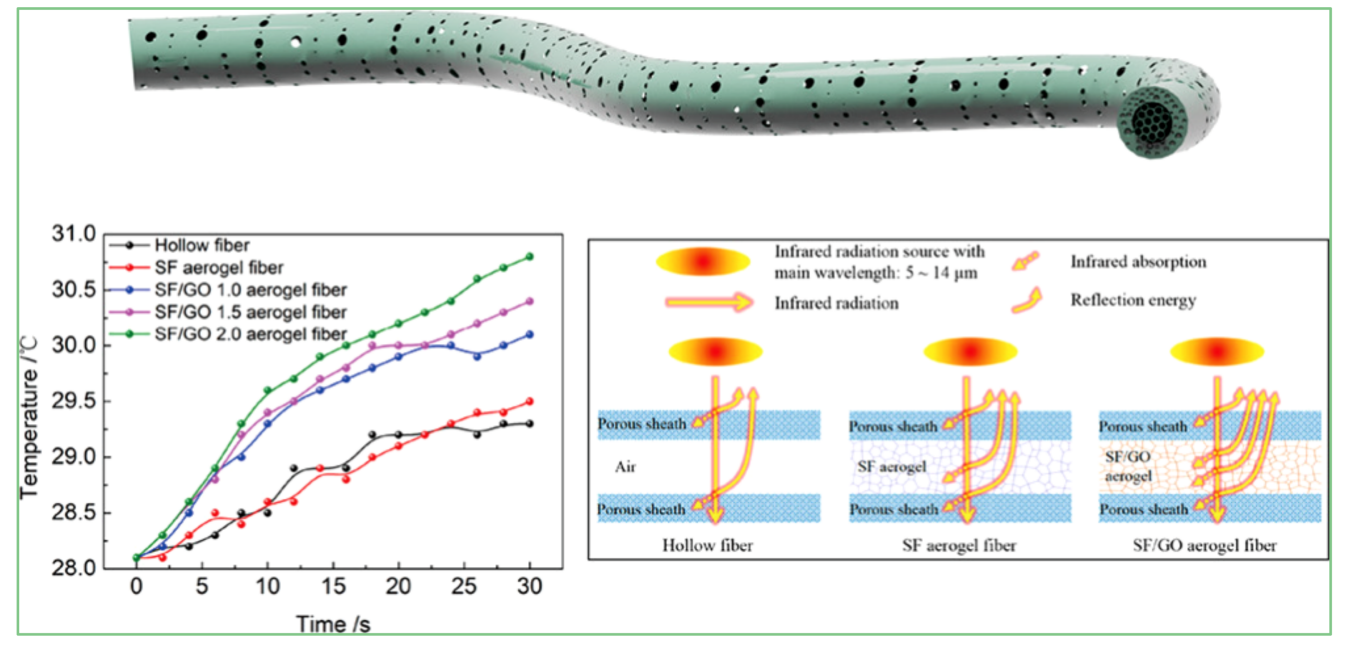

Figure 18. Radiative heating properties of SF/GCA fibers [64].

In short, the introduction of graphene-based materials improves the thermal performance of aerogel and provides a scheme to overcome the problem of energy consumption [65], which gives it great application potential in thermal insulation materials, flame retardant materials, and electronic devices.

\subsection{Electrochemical Properties}

The ultra-high electrical conductivity of graphene is one of its most attractive characteristics, which can reach $10^{7}-10^{8} \mathrm{~S} / \mathrm{cm}$, and makes it possible to prepare GCA with excellent electrical performance [66]. However, due to the contact resistance between graphene nanosheets, the electrical conductivity of GCA usually decreases significantly. There are two common methods to further increase the electrical properties of graphene aerogels. The first method is to introduce conductive polymers or doping metal oxides into the aerogel, and the synergistic effect between components can improve the electrical conductivity and structural stability of the polymer/GCA. The second method is to uniformly coat conductive polymer/GA materials on the substrate by spraying or spinning [67], which will significantly improve the conductivity of the aerogel as a supercapacitor and energy storage material.

Common metal oxides such as $\mathrm{Fe}_{2} \mathrm{O}_{3}, \mathrm{Co}(\mathrm{OH}), \mathrm{Co}_{3} \mathrm{O}_{4}, \mathrm{MnO}_{2}$, and $\mathrm{MoS}_{2}$ increase the electrical conductivity of GCA. For example, with the hydrothermal method, GCA was obtained by doping nano- $\mathrm{Fe}_{2} \mathrm{O}_{3}$ into graphene aerogel, and its specific capacitance was $81.3 \mathrm{~F} \cdot \mathrm{g}^{-1}$ at a constant current density of $1 \mathrm{~A} \cdot \mathrm{g}^{-1}$ and working potential of $-0.8-0.8 \mathrm{~V}$. GCA can also be functionalized by $\mathrm{O}, \mathrm{N}, \mathrm{S}, \mathrm{B}$, etc. [68]. Yun et al. [69] doped $\mathrm{N}$ into carbon quantum dots (CQDs) and then combined them with rGO and different ratios of $\mathrm{Fe}_{2} \mathrm{O}_{3}$ to produce GCA by form N-CQDs $/ \mathrm{rGO} / \mathrm{Fe}_{2} \mathrm{O}_{3}$ composite, and the preparation process is shown in Figure 19. The composite aerogel had excellent electrochemical performance and ultra-high specific capacity due to its high surface area and porous layered structure, as well as the synergistic effect of high-capacity $\mathrm{Fe}_{2} \mathrm{O}_{3}$ and stable high-conductivity N$\mathrm{CQD} / \mathrm{rGO}$. The proper doping proportion can further improve electrical conductivity [70]. Yang et al. [71] successfully prepared 3D MXene/rGO composite aerogel by the ice template method and coating with carboxylated polyurethane (PU). This not only had excellent electrochemical performance, but also good self-healing ability, and the capacitance retention rate reached $91 \%$ in 15,000 cycles, providing a method for use in long-life multi-function electronic devices. Therefore, the preparation of GCA with excellent electrochemical performance, whether coated with polymer conductive materials or doped with inorganic nanoparticles or multicomponent composites, mainly depends on the filler ratio, the inherent electrical conductivity of the graphene-based nanosheets and materials used, and the control of the micro-morphology. 


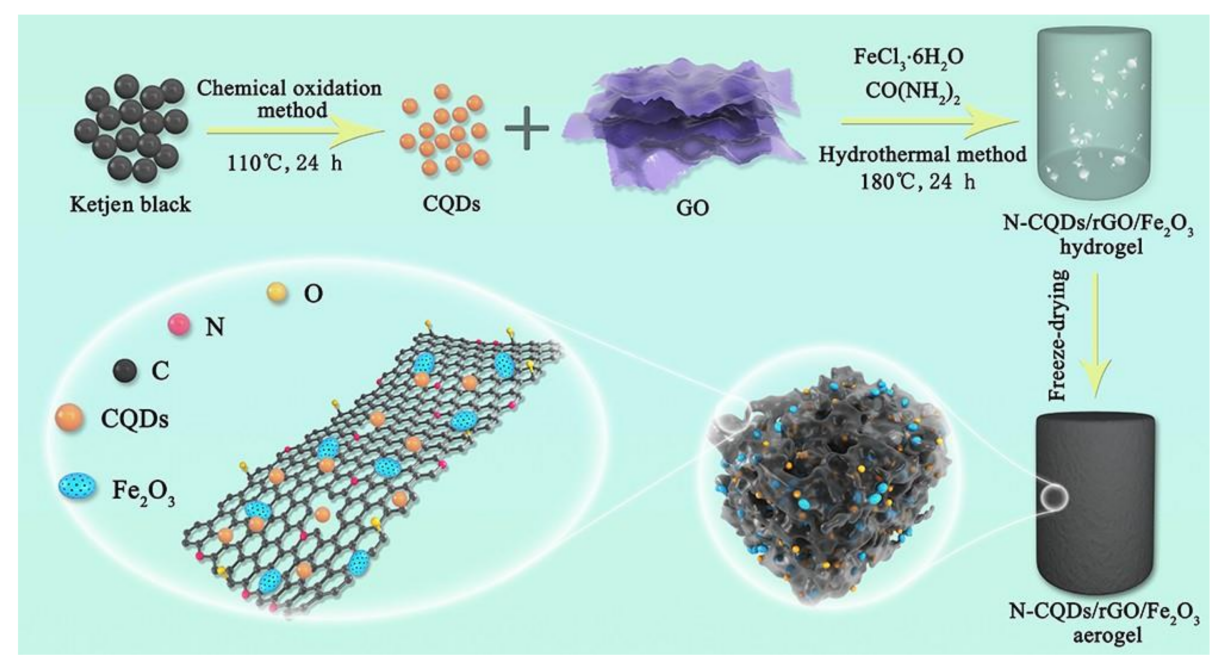

Figure 19. Schematic demonstration of GCA aerogel synthesis [67].

\section{Application of GCA}

\subsection{Adsorption Removal of Contaminants from Water}

Adsorption is a popular sewage treatment because of low cost, simple operation, large adsorption capacity, and high removal rate [72]. GCA is an ideal adsorbent for sewage treatment owing to its higher adsorption capacity and easy reuse [73]. Zang et al. found that more porous CS/GCA had good adsorption and removal effects for $\mathrm{Pb}^{2+}$. When the GO content in the aerogel was $5 \mathrm{wt} \%$, the adsorption capacity of $\mathrm{Pb}^{2+}$ increased from 68.5 to $100 \mathrm{mg} \cdot \mathrm{g}^{-1}$. The adsorption mechanism of common metal ions $\mathrm{Pb}^{2+}$ and $\mathrm{Cu}^{2+}$ may consist of intergroup coordination and complexation (Figure 20) [74].

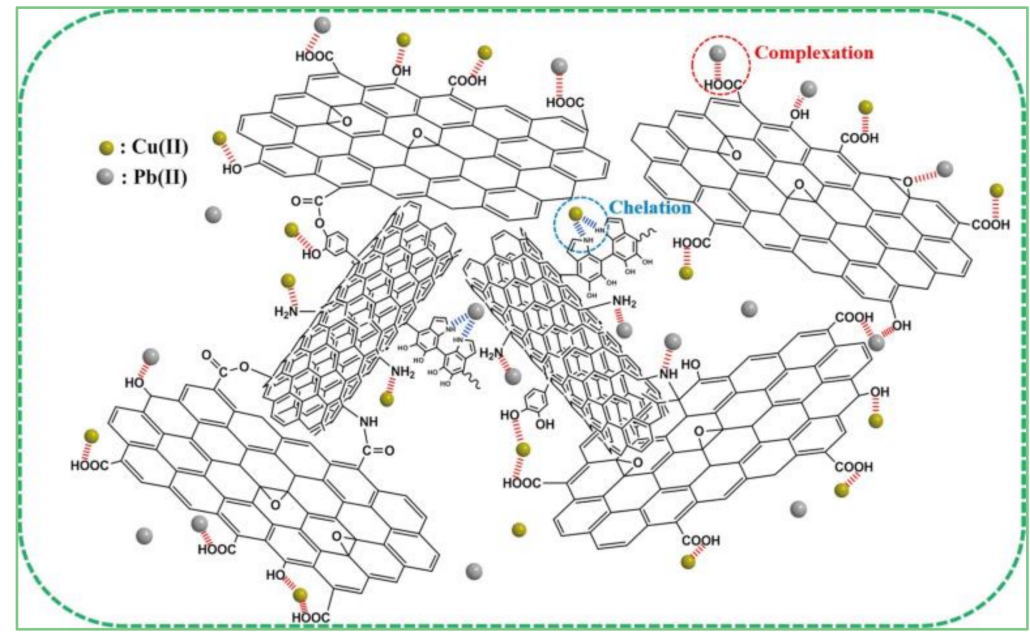

Figure 20. Complexation (red) and communication (blue) interactions of $\mathrm{Pb}$ (II) and $\mathrm{Cu}$ (II) adsorption on GCA [74].

The surface properties of the adsorbent and the chemical properties (structure, hydrophobicity, polarity) of the aerogels [75] determine the types of pollutants that can be adsorbed [76]. Preparation of GCA with high hydrophobicity and high specific surface area provides a feasible solution for the removal of organic oil pollution. Yang et al. [77] introduced fluoroalkyl-silane into GCA by gas-liquid deposition to obtain superhydrophobic graphene aerogels (SGAs) with super hydrophobicity, super lipophilicity, ultra-low density, large specific surface area, excellent adsorption capacity, and adsorption recycling (Figure 21), which has great potential in the field of oil-water separation. 
Table 3 lists the studies on the adsorption properties of GCA for heavy metals, organic compounds, dyes, and other pollutants. In terms of recyclability, most studies have shown that recovery and desorption efficiency were improved by selecting suitable desorbents (acids, alkalis, and organic solvents), and the 3D structure of GA had a unique effect in this regard [78]. This shows that GCA has broad prospects in adsorption treatment of water pollution.

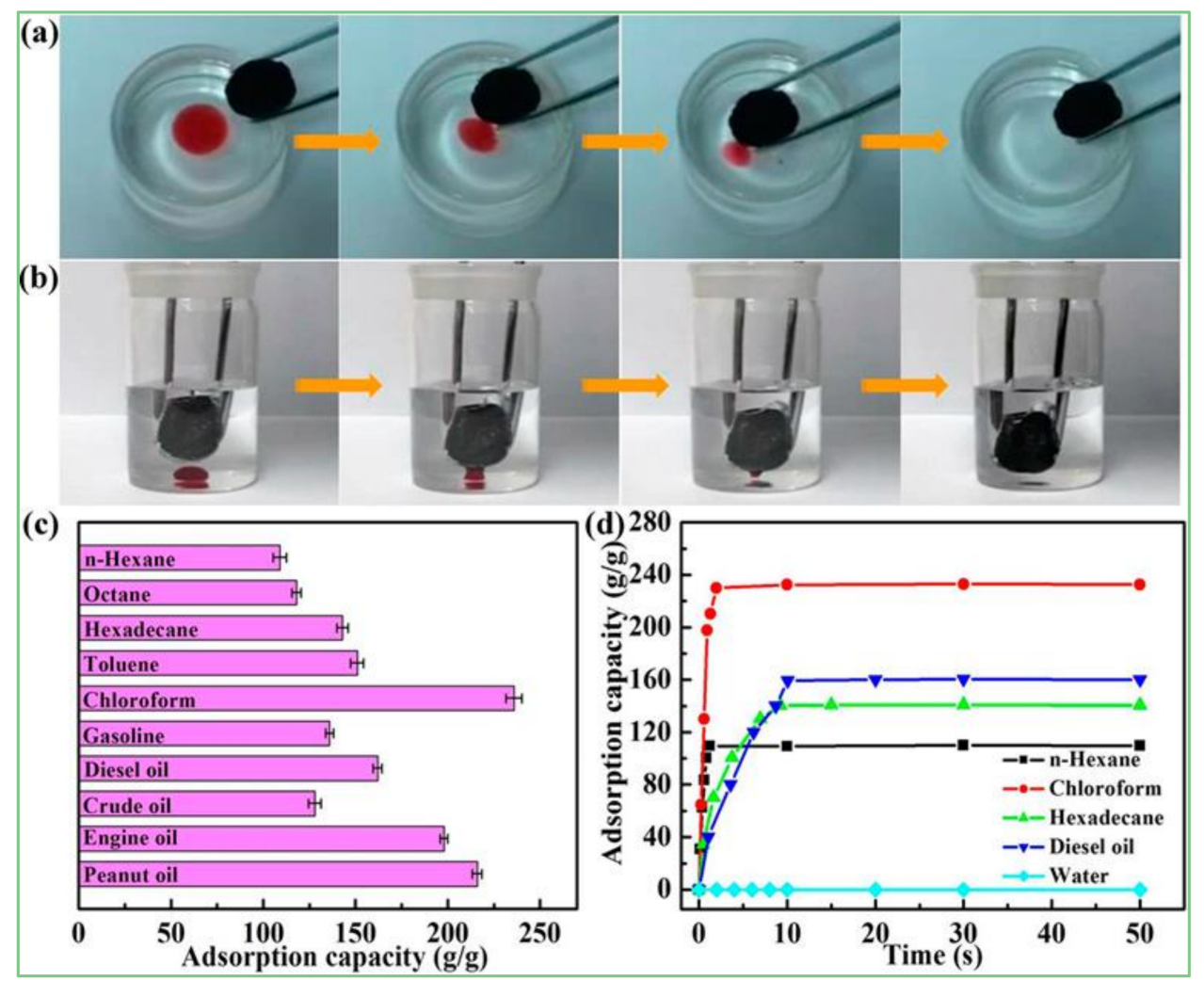

Figure 21. Adsorption performance of SGAs for oil. (a) Snapshots showing the SGAs adsorbs hexadecane (dyed by oil red) floating on the water; (b) Snapshots showing the SGAs adsorbs chloroform (dyed by oil red) from the bottom of the water; (c) The adsorption capacity of the SGAs for various kinds of organic solvents and oils; (d) The time-dependent sorption behaviour of various oily compounds and water by the SGAs [77].

Table 3. Adsorption properties of different GCAs.

\begin{tabular}{|c|c|c|c|c|c|}
\hline Adsorbent & Contaminants & Adsorption Conditions & $\begin{array}{l}\text { Isotherm } \\
\text { Model }\end{array}$ & $\underset{\left(\mathrm{mg} \cdot \mathrm{g}^{-1}\right)}{\mathrm{q}_{\mathrm{m}}}$ & Reference \\
\hline RGO/ZIF-67 & $\begin{array}{l}\mathrm{CV} \\
\mathrm{MO}\end{array}$ & $\mathrm{pH} 3-9, \mathrm{~T}=298 \mathrm{~K}, \mathrm{t}=0-16 \mathrm{~h}$ & Langmuir & $\begin{array}{c}1714 \\
426\end{array}$ & [79] \\
\hline MWCNT-PDA & $\begin{array}{l}\mathrm{Cu}^{2+} \\
\mathrm{Pb}^{2+}\end{array}$ & $\mathrm{pH} 2-7, \mathrm{~T}=298 \mathrm{~K}, \mathrm{t}=0-10 \mathrm{~h}$ & Langmuir & $\begin{array}{l}318.47 \\
350.87\end{array}$ & [74] \\
\hline $3 \mathrm{D}-\mathrm{Fe}_{3} \mathrm{O}_{4} / \mathrm{GA}$ & $\mathrm{As}^{5+}$ & $\mathrm{pH} 7, \mathrm{~T}=298 \mathrm{~K}, \mathrm{t}=0-16 \mathrm{~h}$ & Langmuir & 40.05 & [80] \\
\hline 3D-SRGO & $\mathrm{Cd}^{2+}$ & $\mathrm{pH} 2-9, \mathrm{~T}=298 \mathrm{~K}, \mathrm{t}=0-24 \mathrm{~h}$ & Langmuir & 234.8 & [81] \\
\hline $\mathrm{GA} / \mathrm{SiO}_{2}$ & $\begin{array}{c}\mathrm{Hg}^{2+} \\
\mathrm{Pb}^{2+}\end{array}$ & $\mathrm{pH} 2-10, \mathrm{~T}=296 \mathrm{~K}, \mathrm{t}=0-1.5 \mathrm{~h}$ & Langmuir & $\begin{array}{c}500.0 \\
643.62\end{array}$ & [82] \\
\hline $3 \mathrm{D} \delta-\mathrm{MnO}_{2}$ & $\begin{array}{l}\mathrm{Cd}^{2+} \\
\mathrm{Cu}^{2+}\end{array}$ & $\mathrm{pH} 2-6, \mathrm{~T}=298 \mathrm{~K}, \mathrm{t}=0-3 \mathrm{~h}$ & Langmuir & $\begin{array}{l}250.31 \\
228.46\end{array}$ & [83] \\
\hline 3D GO/SA & MB & $\mathrm{pH} 4-9, \mathrm{~T}=293 \mathrm{~K}, \mathrm{t}=0-24 \mathrm{~h}$ & Langmuir & 4.25 & {$[84]$} \\
\hline PAM/GO & Magenta & $\mathrm{pH} 2.6-8.9, \mathrm{~T}=303 \mathrm{~K}, \mathrm{t}=0-55 \mathrm{~h}$ & Langmuir & 1034.3 & [85] \\
\hline GO-AL & MB & $\mathrm{pH} 3.0, \mathrm{~T}=303 \mathrm{~K}, \mathrm{t}=0-4 \mathrm{~h}$ & Langmuir & 1185.98 & [86] \\
\hline PPGA & N-hexane, MO & $\mathrm{pH} 3.0, \mathrm{~T}=303 \mathrm{~K}, \mathrm{t}=0-4 \mathrm{~h}$ & Langmuir & $\begin{array}{c}63.5 \\
202.8\end{array}$ & [87] \\
\hline
\end{tabular}


Table 3. Cont.

\begin{tabular}{|c|c|c|c|c|c|}
\hline Adsorbent & Contaminants & Adsorption Conditions & $\begin{array}{l}\text { Isotherm } \\
\text { Model }\end{array}$ & $\underset{\left(\mathrm{mg} \cdot \mathrm{g}^{-1}\right)}{\mathrm{q}_{\mathrm{m}}}$ & Reference \\
\hline RGO/REMO & $\begin{array}{c}\text { RhB, } \\
\text { phenol, }\end{array}$ & $t=0-24 h$ & Langmuir & $\begin{array}{c}243.4 \\
90\end{array}$ & [88] \\
\hline GAS-MS & $\begin{array}{l}\text { catechol, } \\
\text { resorcinol, } \\
\text { hydroquinone }\end{array}$ & $\mathrm{pH} 3.0, \mathrm{~T}=298 \mathrm{~K}, \mathrm{t}=24 \mathrm{~h}$ & Langmuir\&Freundlich & $\begin{array}{l}66 \\
22 \\
67\end{array}$ & [28] \\
\hline $\mathrm{CNF} / \mathrm{GO}$ & Tetracycline & $\mathrm{pH} 2-12, \mathrm{~T}=298 \mathrm{~K}, \mathrm{t}=24 \mathrm{~h}$ & Langmuir & 454.6 & [89] \\
\hline 3DG & Methyl bromide & $\mathrm{pH} 7.5, \mathrm{~T}=298 \mathrm{~K}, \mathrm{t}=0-5 \mathrm{~h}$ & Langmuir & 685 & [90] \\
\hline
\end{tabular}

RGO/ZIF-67, three-dimensional rGO/zeolitic imidazolate framework-67 aerogel; MWCNT-PDA, graphene/polydopamine modified multiwalled carbon nanotube hybrid aerogel; 3D-SRGO, 3D sulfonated reduced $\mathrm{GO}$ aerogel; 3D $\delta-\mathrm{MnO}_{2}, 3 \mathrm{D}$ graphene/delta- $\mathrm{MnO}_{2}$ aerogel; GO-AL, GO/alkali lignin aerogel composite; PPGA, polydopamine and poly-ethylenimine co-functionalized GO aerogel; RGO/REMO, RGO/rare earth-metal oxide aerogel; GAS-MS, 3D graphene aerogel-mesoporous silica; CNF/GO, cellulose nanofibril/graphene oxide hybrid aerogel; 3DG, three-dimensional graphene aerogel.

\subsection{Application of Sensors and Supercapacitors}

The unique porous structure of GCA gives it good flexibility and elasticity, and it has become the preferred material for piezoelectric resistance sensors. In addition, GCA has great application potential in the field of energy storage and sensing, including supercapacitors, lithium batteries, solar cells, and fuel cells, because of its high conductivity, high electrochemical stability, and good mechanical stability [91].

Pressure sensitivity plays a key role in piezoelectric resistance materials, which determines the sensitivity of resistance materials. Generally, a highly sensitive aerogel can be obtained by controlling the composition of the GCA. Wei et al. [92] used borate as a reinforcing material in a $3 \mathrm{D}$ graphene aerogel structure to obtain nitrogen and boron co-modification (NBGC) aerogel with excellent elasticity and compressibility and good electrochemical properties. This kind of aerogel provided a fast external stress change current response with specific capacitance up to $336 \mathrm{~F} \cdot \mathrm{g}^{-1}$; when the stress increased from $0.05 \mathrm{~N}$ to $10 \mathrm{~N}$, the response current varied from $0.44-2.89 \mathrm{~mA}$ to $10 \mathrm{~N}$, so it could be applied in high-performance stress sensors (Figure 22).

The application of GCA in energy storage is shown in Table 4. The introduction of polymer or inorganic nano-active materials into the aerogel structure improves the electrochemical energy storage of super capacitors [93]. For example, using high-conductivity $\mathrm{Cu} / \mathrm{Cu}_{\mathrm{x}} \mathrm{O}$ to modify the rGO network structure, $\mathrm{C}$ aerogel with high apparent conductivity was obtained [94], which was two to three orders of magnitude higher than pure graphene aerogel $(0.1 \mathrm{~S} / \mathrm{m})$. Li et al. [88] designed a new type of PPy layer coated sulfur/GCA by vapor deposition, which was used as the cathode of a lithium-sulfur battery. PPy as a uniform coating ensures long-time, stable cycle performance of lithium-sulfur batteries, and it also has excellent electrochemical properties, such as high specific capacity. The discharge capacity at $0.2 \mathrm{C}$ after 500 cycles reached $1167 \mathrm{mAh} \cdot \mathrm{g}^{-1}$ after 500 cycles. In addition, Table 4 also shows that the electrochemical energy storage and conductivity of GCA doped with heteroatoms $\mathrm{N}$ or $\mathrm{B}$ are greatly improved, and the active specific surface area is increased. The synergistic effect of $\mathrm{N}$ and $\mathrm{B}$ co-doping promotes the charge transfer between adjacent carbon atoms, improves the electrochemical performance of carbon-based materials, and gives them excellent power density and charge-discharge rate, which makes this a very promising super energy storage capacitor material [95]. This shows that 3D GCA has great research value with regard to energy storage materials. In the future, designing GCA with a porous structure and a larger specific surface area, while maintaining a good conductive path for effective charge transfer, is a problem that researchers will need to pay attention to. 


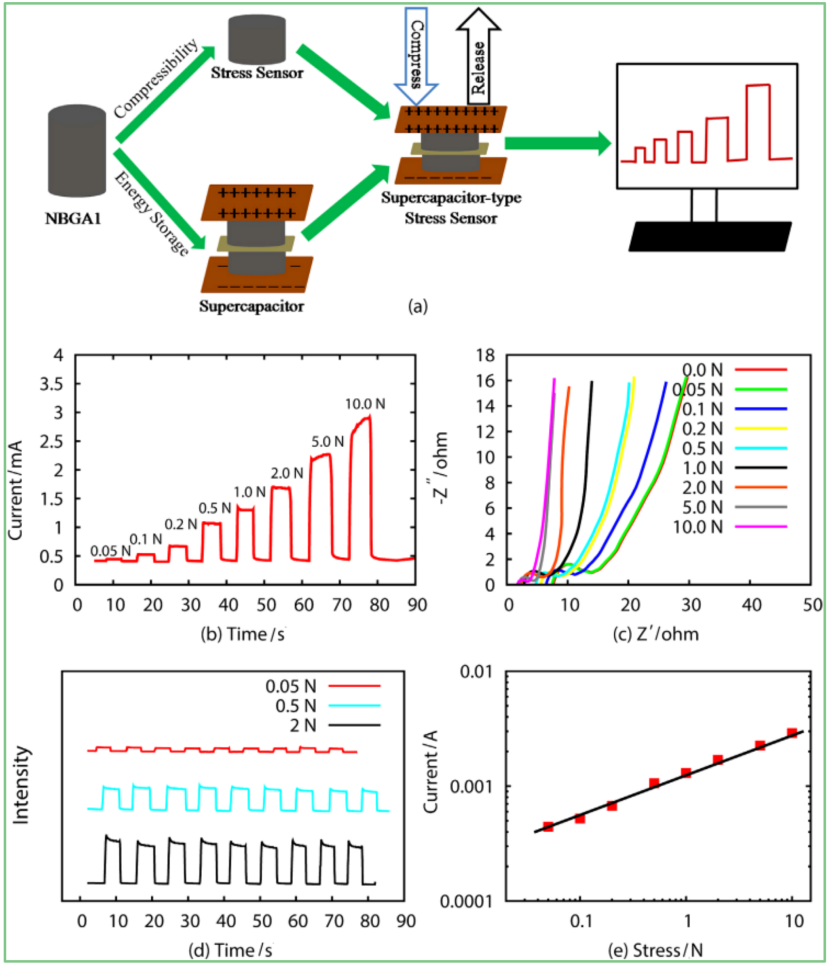

Figure 22. Electrochemical and pressure response performance of NBGC aerogel as supercapacitor and stress sensor. (a) A schematic illustration of assembled NBGC aerogel as a supercapacitor stress sensor; (b) The response currentetime (Iet) characteristic curves of the NBGC aerogel stress sensor at different stress (T) of 0.05e10 N; (c) The EIS of the cell under different stress; (d) The stress sensor cycle stability of device at different stress of $0.05 \mathrm{~N}, 0.5 \mathrm{~N}$ and $2 \mathrm{~N}$, respectively; (e) The relationship between the response current and the stress. [92].

Table 4. Energy storage performance of different GCA materials.

\begin{tabular}{|c|c|c|c|c|c|}
\hline $\begin{array}{c}\text { Composite } \\
\text { Aerogel Materials }\end{array}$ & $\begin{array}{c}\text { Specific } \\
\text { Capacitance } \\
\left(\mathrm{F} \cdot \mathrm{g}^{-1}\right)\end{array}$ & $\begin{array}{l}\text { Energy Density } \\
\quad\left(\mathrm{Wh} \cdot \mathrm{kg}^{-1}\right)\end{array}$ & Cyclic Behavior & Electrolyte & Reference \\
\hline $\mathrm{F}-\mathrm{Fe}_{2} \mathrm{O}_{3} @ \mathrm{MGA}$ & $1119 @ 1 \mathrm{Ag}^{-1}$ & 800 & $98.9 \%$ after 2000 cycles & $3 \mathrm{M} \mathrm{KOH}$ & [96] \\
\hline $\mathrm{LMP} / \mathrm{rGO}$ & $4645 @ 0.5 \mathrm{Ag}^{-1}$ & 11.79 & $91.2 \%$ after 10,000 cycles & $6 \mathrm{M} \mathrm{KOH}$ & [97] \\
\hline $\mathrm{PANI} / \mathrm{CRGO} / \mathrm{Co}_{3} \mathrm{O}_{4}$ & $1247 @ 1 \mathrm{Ag}^{-1}$ & 190 & $92 \%$ after 3500 cycles & $6 \mathrm{M} \mathrm{KOH}$ & [90] \\
\hline PPy/CRGO & $304 @ 0.5 \mathrm{Ag}^{-1}$ & / & $58 \%$ after 50 cycles & $6 \mathrm{M} \mathrm{KOH}$ & [98] \\
\hline GR-CNT & $375 @ 1 \mathrm{Ag}^{-1}$ & / & $94.8 \%$ after 5000 cycles & $6 \mathrm{M} \mathrm{KOH}$ & [99] \\
\hline CA & $467 @ 20 \mathrm{Ag}^{-1}$ & 22.75 & $90.9 \%$ after 10,000 cycles & $1 \mathrm{M} \mathrm{KOH}$ & [100] \\
\hline N,S-MGA & $4929 @ 2 \mathrm{Ag}^{-1}$ & 686.7 & $98.7 \%$ after 5000 cycles & $1 \mathrm{M} \mathrm{KOH}$ & [101] \\
\hline $\mathrm{SnO}_{2}-\mathrm{GA}$ & $541 @ 5 \mathrm{Ag}^{-1}$ & 160 & $97.3 \%$ after 10,000 cycles & $3 \mathrm{M} \mathrm{KOH}$ & [102] \\
\hline $\mathrm{MnO}_{2} / \mathrm{P}-\mathrm{RGO}$ & $645 @ 1 \mathrm{Ag}^{-1}$ & 59.2 & $94.6 \%$ after 10,000 cycles & $1 \mathrm{M} \mathrm{Na}_{2} \mathrm{SO}_{4}$ & [103] \\
\hline
\end{tabular}

F- $\mathrm{Fe}_{2} \mathrm{O}_{3} @ \mathrm{MGA}$, flower-like $\mathrm{Fe}_{2} \mathrm{O}_{3} @$ multiple graphene aerogel; LMP/rGO, LiMnPO$/$ reduced $\mathrm{GO}$ aerogel; $\mathrm{PANI} / \mathrm{CRGO} / \mathrm{Co}_{3} \mathrm{O}_{4}$, self-assembled graphene/polyaniline $/ \mathrm{Co}_{3} \mathrm{O}_{4}$ ternary hybrid aerogel; $\mathrm{PPy} / \mathrm{CRGO}$, conductive graphene/poly-pyrrole hybrid aerogel; GR-CNT, nitrogen-doped carbon aerogel; CA, nitrogen-doped carbon aerogel; $\mathrm{N}, \mathrm{S}-\mathrm{MGA}$, nitrogen and sulfur-functionalized multiple graphene; $\mathrm{MnO}_{2}$ / $\mathrm{P}-\mathrm{RGO}$, phytic acid modified manganese dioxide/GCA.

\subsection{Application of Heat-Insulation and Flame-Retardant Materials}

Aerogels have unparalleled advantages as thermal insulation materials. The reason is that the ultra-high porosity of aerogel reduces heat conduction, and the pore walls in the aerogel network can effectively restrain thermal radiation. When the aerogel has smaller pore size, thermal convection will be reduced [104]. Some polymer aerogels, such as PVA [105], cellulose [106], and pectin [107] aerogels, are excellent thermal insulation 
materials, but their application is limited because of poor thermal stability and flame retardancy. Fortunately, carbon nanomaterials such as graphene materials can improve the physical and thermal properties of polymer aerogels. Because the density, porosity, and complex skeleton structure have an influence on the porous thermal insulation materials, composite aerogel with low density, low thermal conductivity, and high strength prepared by quartz fiber and nitrogen-doped graphene has great application potential in aviation for thermal insulation.

In terms of flame-retardant materials, highly thermal stable graphene aerogel with large porosity eliminates heat rapidly during combustion [108]. Hence, taking advantage of the flame retardancy of graphene aerogel and the low thermal conductivity of composite, aerogels prepared with phenolic resin have ultra-low thermal conductivity, high thermal stability, and good flame retardancy [109]. Ceramic fillers with $\mathrm{Al}_{2} \mathrm{O}_{3}$ ceramic and graphene have been designed with a layered honeycomb microstructure, showing a coupling strengthening effect between the graphene skeleton and the $\mathrm{Al}_{2} \mathrm{O}_{3}$ ceramic nanolayer. The composite aerogel not only has ultra-light density, reversible compressibility, and high electrical conductivity, but also great application prospects in flame retardancy, thermal insulation, and so on [110].

\subsection{Biomedical Applications}

In the biomedical field, some degrees of biocompatibility, biodegradability and antibacterial properties of graphene-based materials are beneficial [111]. The toxicity of graphene-based materials is related to many aspects such as content, size, surface chemistry, cell lines, morphologies, administration route, etc., and this is also applicable to similar GCA studies [112]. For example, in the study of GCA used in in situ bone regeneration, the content of nano graphene-based materials can affect the biocompatibility and biodegradability of GCA, and the content of GO is $0.10 \%$ aerogel is more conducive to cell increment [113]. Nanoscale small-sized GO has a lower level of cytotoxicity so that it can be used as a drug delivery carrier; the graphene aerogel nanoparticles (GANPs) were prepared as drug delivery carriers with high $\mathrm{pH}$ sensitivity, and released after 5 days in vivo, and are expected to be used in nanomedicine in the future [114]. The toxicity of graphene-based materials is different in vivo and in vitro, which is affected by their physical and chemical properties, such as functional groups, charges, sizes, stiffness, hydrophobicity and structural defects [112]. Luo et al. synthesized three-dimensional multi-functional GCA materials using tannic acid as raw material, which showed high porosity, low density, good hydrophobicity, good mechanical properties, high thermal stability, strong antibacterial properties, and sterilization rates of 58.12 and $99.99 \%$ for Escherichia coli and Staphylococci, respectively [115]. Therefore, a large number of studies in the biomedical field have focused on its safety and reducing its cytotoxicity, such as through the introduction of some biocompatible materials such as chitosan, collagen, gelatin, serum albumin and so on [116]. In addition, graphene-based nanosheets are used as structural reinforcement materials to prevent cells from collapsing during growth, thus stabilizing the three-dimensional structure, which is more obvious in the case of good dispersion of nanoparticles and good affinity of polymer fillers. For example, a thin biocompatible coating can be formed on the surface of three-dimensional graphene, which can be used as a high-strength biocompatible scaffold material for nervous system regeneration and musculoskeletal tissue engineering. This presented good tissue integrity renewal ability and inhibition of lesion expansion after spinal cord injury [117].

Furthermore, these materials could also be applied as biosensors to provide a wealth of information for early diagnosis of diseases and prevention of their evolution [118]. Composite material modified with 3D GCA and nano- $\mathrm{CuO}$, with high sensitivity, was exploited as a biosensor for the detection of ascorbic acid [119]. Graphene aerogel was shown to detect dopamine with high sensitivity $\left(619.6 \mu \mathrm{A} \cdot \mu \mathrm{M}^{-1} \cdot \mathrm{cm}^{-2}\right)$, which was attributed to the highly conductive 3D multichannel, high charge transfer rate, and efficient transport guaranteed by the close interaction between dopamine and graphene [120]. The multifunctional 
silica/GCA material can be used as a biosensor for the detection of insulin (INS) with high selectivity and sensitivity [121]. The extensive research on GCA in the biomedical field is focused on its convenience as a drug carrier, antibacterial, biological scaffold, sensor, and so on. Designing GCA material with flexible biological and intelligent properties in the future will broaden its application in the biomedical field. Research on GCA in biomedicine has great potential, and is worth promoting further.

\section{Conclusions and Outlook}

This paper reviews the material composition, preparation methods, structural characteristics, properties, and applications of GCA. Here we focus on several types of GCA, including graphene-based/2D nanomaterial (MXenes) aerogel for sensors and supercapacitors, graphene-based/inorganic nanomaterial $\left(\mathrm{SiO}_{2}, \mathrm{SnO}_{2}, \mathrm{SnO}_{2}, \mathrm{TiO}_{2}\right)$ aerogel and heat-insulating flame-retardant materials, and graphene-based/synthetic polymer aerogel and graphene-/natural sugar-based polymer aerogel used as adsorbents to remove metal ions and dye contaminants in water.

In addition, this paper also describes the influence of differences in the morphological structure (specific surface area, density, pore size, etc.) of GCA on its mechanical, thermal, and electrochemical properties. At the same time, the commonly used methods for preparing GCA are briefly described, including template method, self-assembly, chemical vapor deposition, 3D printing, and performance improvement strategies (doping, coating, cross-linking). GCA not only makes up for the deficiencies in the mechanical properties of graphene aerogel, but also retains excellent electrical conductivity, good mechanical flexibility, low thermal expansion coefficient, and other physical properties. It meets the special requirements for material properties in new fields, such as environmental purification, sensing, energy storage, biomedicine, heat insulation, and fire protection, and has become a hot spot in the field of graphene research in recent years. However, at present, the preparation method of graphene aerogel is relatively cumbersome, and it is necessary to find a quick preparation method to realize large-scale industrial production, although the chemical exfoliation method described in previous studies can be used to easily prepare graphene and its derivatives on a large scale. This still needs to be optimized to control the structure and size of materials. In terms of well-designed GCA, it is necessary to further explore the relationship between its properties and microstructure and optimize the preparation process parameters. For example, in the previous introduction, the pore structure of the aerogel was adjusted by controlling the formation of ice crystals between graphene sheets, but it is difficult to obtain uniform pore structure due to the existence of a temperature gradient, so it is still a difficult problem to skillfully control the morphology and size distribution of the product. In addition, most of the research has remained in the laboratory stage. Researchers should combine studies with production demand and broaden the scope of application.

In summary, the future research direction of GCA will move toward the design and preparation of new graphene derivatives and their composite materials, with multidimensionality and better performance. Compared with GCA, it is difficult to use other materials in so many areas, especially energy storage, sensing, and adsorption, which are based on the characteristics of graphene-based and aerogel materials. With the continuous advancement of science and technology, GCA that is more environmentally friendly and has excellent application performance and better structural properties will be prepared in the future, which is both an opportunity and a challenge.

Author Contributions: Conceptualization, S.L. and X.L.; methodology, X.L. and S.L.; data curation, X.L., L.L. and D.W.; writing-original draft preparation, X.L. and S.L.; writing-review and editing, S.L., X.L., D.W. and L.L.; investigation, X.L., S.L., Y.H., L.W. and Z.L.; project administration, S.L.; funding acquisition, S.L. All authors have read and agreed to the published version of the manuscript. 
Funding: This research was funded by the Innovational Industrialization Foundation of Shaanxi Province of China (grant number 2021QFY04-04) and the National Natural Science Foundation of China (grant number 21276152).

Institutional Review Board Statement: Not applicable.

Informed Consent Statement: Not applicable.

Data Availability Statement: Publicly available datasets were analyzed in this study. This data can be found here: https:/ / www.webofscience.com/wos/alldb/basic-search (accessed on 25 November 2021).

Conflicts of Interest: We declare that we have no financial and personal relationships with other people or organizations that could inappropriately influence our work.

\section{References}

1. ElKhatat, A.M.; Al-Muhtaseb, S.A. Advances in tailoring resorcinol-formaldehyde organic and carbon gels. Adv. Mater. 2011, 23, 2887-2903. [CrossRef] [PubMed]

2. Guo, F.; Jiang, Y.; Xu, Z.; Xiao, Y.; Fang, B.; Liu, Y.; Gao, W.; Zhao, P.; Wang, H.; Gao, C. Highly stretchable carbon aerogels. Nat. Commun. 2018, 9, 881. [CrossRef]

3. Khetib, Y.; Alahmadi, A.A.; Alzaed, A.; Sajadi, S.M.; Cheraghian, G.; Sharifpur, M. Numerical study of the effect of graphene nanoparticles in calcium chloride hexahydrate-based phase change material on melting and freezing time in a circular cavity with a triangular obstacle. J. Energy Storage 2021, 43, 103243. [CrossRef]

4. Abidi, A.; Rawa, M.; Khetib, Y.; Sindi, H.F.A.; Sharifpur, M.; Cheraghian, G. Simulation of melting and solidification of graphene nanoparticles-PCM inside a dual tube heat exchanger with extended surface. J. Energy Storage 2021, 44, 103265. [CrossRef]

5. Bi, H.; Yin, K.; Xie, X.; Zhou, Y.; Wan, N.; Xu, F.; Banhart, F.; Sun, L.; Ruoff, R.S. Low temperature casting of graphene with high compressive strength. Adv. Mater. 2012, 24, 5124-5129. [CrossRef]

6. Cheng, C.; Li, S.; Thomas, A.; Kotov, N.A.; Haag, R. Functional graphene nanomaterials based architectures: Biointeractions, fabrications, and emerging biological applications. Chem. Rev. 2017, 117, 1826-1914. [CrossRef]

7. $\quad$ Olszowska, K.; Pang, J.; Wrobel, P.S.; Zhao, L.; Ta, H.Q.; Liu, Z.; Trzebicka, B.; Bachmatiuk, A.; Rummeli, M.H. Three-dimensional nanostructured graphene: Synthesis and energy, environmental and biomedical applications. Synth. Met. 2017, $234,53-85$. [CrossRef]

8. $\quad$ Kistler, S.S. Coherent expanded aerogels and jellies. Nature 1931, 127, 741. [CrossRef]

9. Brown, E.; Yan, P.; Tekik, H.; Elangovan, A.; Wang, J.; Lin, D.; Li, J. 3D printing of hybrid MoS $_{2}$-graphene aerogels as highly porous electrode materials for sodium ion battery anodes. Mater. Des. 2019, 170, 107689. [CrossRef]

10. Li, Y.; Meng, F.; Mei, Y.; Wang, H.; Guo, Y.; Wang, Y.; Peng, F.; Huang, F.; Zhou, Z. Electrospun generation of Ti ${ }_{3} \mathrm{C}_{2} \mathrm{Tx}_{\mathrm{M}} \mathrm{M}$ Xene@ graphene oxide hybrid aerogel microspheres for tunable high-performance microwave absorption. Chem. Eng. J. 2020, 391,123512 [CrossRef]

11. Fu, X.; Choi, J.-Y.; Zamani, P.; Jiang, G.; Hoque, M.A.; Hassan, F.M.; Chen, Z. Co-N decorated hierarchically porous graphene aerogel for efficient oxygen reduction reaction in acid. ACS Appl. Mater. Interfaces 2016, 8, 6488-6495. [CrossRef]

12. Wang, Y.; Wang, L.; Zhu, H.W. Wearable and highly sensitive graphene strain sensors for human motion monitoring. Adv. Funct. Mater. 2014, 24, 4666-4670.

13. Cheng, L.; Qiao, D.; Zhao, P.; He, Y.; Sun, W.; Yu, H.; Jiao, Z. Template-free synthesis of mesoporous succulents-like TiO2/graphene aerogel composites for lithium-ion batteries. Electrochim. Acta 2019, 300, 417-425. [CrossRef]

14. Liu, X.; Sun, J.; Zhang, X. Novel 3D graphene aerogel-ZnO composites as efficient detection for $\mathrm{NO}_{2}$ at room temperature. Sens. Actuators B Chem. 2015, 211, 220-226. [CrossRef]

15. Li, W.; Gao, S.; Wu, L.; Qiu, S.; Guo, Y.; Geng, X.; Chen, M.; Liao, S.; Zhu, C.; Gong, Y. High-density three-dimension graphene macroscopic objects for high-capacity removal of heavy metal ions. Sci. Rep. 2013, 3, 2125. [CrossRef]

16. Zhao, Z.; Wang, Z.; Wang, D.; Wang, J.-X.; Foster, N.R.; Pu, Y.; Chen, J.-F. Preparation of 3D graphene/iron oxides aerogels based on high-gravity intensified reactive precipitation and their applications for photo-Fenton reaction. Chem. Eng. Process. 2018, 129, 77-83. [CrossRef]

17. Xiang, Y.; Liu, L.; Li, T.; Dang, Z. Compressible, amphiphilic graphene-based aerogel using a molecular glue to link graphene sheets and coated-polymer layers. Mater. Des. 2016, 110, 839-848. [CrossRef]

18. Zhang, Q.; Xu, X.; Li, H.; Xiong, G.; Hu, H.; Fisher, T.S. Mechanically robust honeycomb graphene aerogel multifunctional polymer composites. Carbon 2015, 93, 659-670. [CrossRef]

19. Ouyang, A.; Cao, A.; Hu, S.; Li, Y.; Xu, R.; Wei, J.; Zhu, H.; Wu, D. Polymer-coated graphene aerogel beads and supercapacitor application. ACS Appl. Mater. Interfaces 2016, 8, 11179-11187. [CrossRef] [PubMed]

20. Zhang, E.; Liu, W.; Liang, Q.; Liu, X.; Zhao, Z.; Yang, Y. Polypyrrole nanospheres@ graphene aerogel with high specific surface area, compressibility, and proper water wettability prepared in dimethylformamide-dependent environment. Polymer 2019, 185, 121974. [CrossRef]

21. Mi, H.-Y.; Jing, X.; Politowicz, A.L.; Chen, E.; Huang, H.-X.; Turng, L.-S. Highly compressible ultra-light anisotropic cellulose/graphene aerogel fabricated by bidirectional freeze drying for selective oil absorption. Carbon 2018, 132, 199-209. [CrossRef] 
22. Ge, X.; Shan, Y.; Wu, L.; Mu, X.; Peng, H.; Jiang, Y. High-strength and morphology-controlled aerogel based on carboxymethyl cellulose and graphene oxide. Carbohydr. Polym. 2018, 197, 277-283. [CrossRef] [PubMed]

23. Wang, C.-C.; Liang, J.; Liao, Y.-H.; Lu, S.-Y. 3D porous graphene nanostructure from a simple, fast, scalable process for high performance flexible gel-type supercapacitors. ACS Sustain. Chem. Eng. 2017, 5, 4457-4467. [CrossRef]

24. Hsan, N.; Dutta, P.; Kumar, S.; Bera, R.; Das, N. Chitosan grafted graphene oxide aerogel: Synthesis, characterization and carbon dioxide capture study. Int. J. Biol. Macromol. 2019, 125, 300-306. [CrossRef] [PubMed]

25. Shan, S.; Tang, H.; Zhao, Y.; Wang, W.; Cui, F. Highly porous zirconium-crosslinked graphene oxide/alginate aerogel beads for enhanced phosphate removal. Chem. Eng. J. 2019, 359, 779-789. [CrossRef]

26. Zhang, H. Ultrathin two-dimensional nanomaterials. ACS Nano 2015, 9, 9451-9469. [CrossRef]

27. Hanemann, T.; Szabó, D.V. Polymer-nanoparticle composites: From synthesis to modern applications. Materials 2010, 3, 3468-3517. [CrossRef]

28. Karamikamkar, S.; Behzadfar, E.; Naguib, H.E.; Park, C.B. Insights into in-situ sol-gel conversion in graphene modified polymerbased silica gels for multifunctional aerogels. Chem. Eng. J. 2020, 392, 123813. [CrossRef]

29. Parameswaranpillai, J.; Joseph, G.; Shinu, K.; Sreejesh, P.; Jose, S.; Salim, N.V.; Hameed, N. The role of SEBS in tailoring the interface between the polymer matrix and exfoliated graphene nanoplatelets in hybrid composites. Mater. Chem. Phys. 2015, 163, 182-189. [CrossRef]

30. Wang, Y.; Su, Y.; Wang, W.; Fang, Y.; Riffat, S.B.; Jiang, F. The advances of polysaccharide-based aerogels: Preparation and potential application. Carbohydr. Polym. 2019, 226, 115242. [CrossRef]

31. Dai, J.; Xie, A.; Zhang, R.; Ge, W.; Chang, Z.; Tian, S.; Li, C.; Yan, Y. Scalable preparation of hierarchical porous carbon from lignin for highly efficient adsorptive removal of sulfamethazine antibiotic. J. Mol. Liq. 2018, 256, 203-212. [CrossRef]

32. Li, Y.; Grishkewich, N.; Liu, L.; Wang, C.; Tam, K.C.; Liu, S.; Mao, Z.; Sui, X. Construction of functional cellulose aerogels via atmospheric drying chemically cross-linked and solvent exchanged cellulose nanofibrils. Chem. Eng. J. 2019, 366, 531-538. [CrossRef]

33. Kontturi, E.; Laaksonen, P.; Linder, M.B.; Gröschel, A.H.; Rojas, O.J.; Ikkala, O. Advanced materials through assembly of nanocelluloses. Adv. Mater. 2018, 30, 1703779. [CrossRef] [PubMed]

34. Wan, C.; Li, J. Graphene oxide/cellulose aerogels nanocomposite: Preparation, pyrolysis, and application for electromagnetic interference shielding. Carbohydr. Polym. 2016, 150, 172-179. [CrossRef]

35. Dogenski, M.; Navarro-Díaz, H.J.; de Oliveira, J.V.; Ferreira, S.R.S. Properties of starch-based aerogels incorporated with agar or microcrystalline cellulose. Food Hydrocoll. 2020, 108, 106033. [CrossRef]

36. Li, J.; Zhang, K.; Zhang, H. Adsorption of antibiotics on microplastics. Environ. Pollut. 2018, 237, 460-467. [CrossRef]

37. Huang, T.; Shao, Y.-W.; Zhang, Q.; Deng, Y.-F.; Liang, Z.-X.; Guo, F.-Z.; Li, P.-C.; Wang, Y. Chitosan-cross-linked graphene oxide/carboxymethyl cellulose aerogel globules with high structure stability in liquid and extremely high adsorption ability. ACS Sustain. Chem. Eng. 2019, 7, 8775-8788. [CrossRef]

38. Frindy, S.; Primo, A.; Ennajih, H.; el Kacem Qaiss, A.; Bouhfid, R.; Lahcini, M.; Essassi, E.M.; Garcia, H.; El Kadib, A. Chitosangraphene oxide films and $\mathrm{CO}_{2}$-dried porous aerogel microspheres: Interfacial interplay and stability. Carbohydr. Polym. 2017, 167, 297-305. [CrossRef]

39. Yu, M.; Zhang, H.; Yang, F. Hydrophilic and compressible aerogel: A novel draw agent in forward osmosis. ACS Appl. Mater. Interfaces 2017, 9, 33948-33955. [CrossRef] [PubMed]

40. Zhang, M.; Xiao, Q.; Chen, C.; Li, L.; Yuan, W. Developing a heat-insulating composite phase change material with light-to-thermal conversion performance from graphene oxide/silica hybrid aerogel. Appl. Therm. Eng. 2020, 174, 115303. [CrossRef]

41. Chen, H.-C.; Lin, Y.-C.; Chen, Y.-L.; Chen, C.-J. Facile fabrication of three-dimensional hierarchical nanoarchitectures of $\mathrm{VO}_{2}$ /graphene@ $\mathrm{NiS}_{2}$ hybrid aerogel for high-performance all-solid-state asymmetric supercapacitors with ultrahigh energy density. ACS Appl. Energy Mater. 2018, 2, 459-467. [CrossRef]

42. Hou, S.; Wu, X.; Lv, Y.; Jia, W.; Guo, J.; Wang, L.; Tong, F.; Jia, D. Ultralight, highly elastic and bioinspired capillary-driven graphene aerogels for highly efficient organic pollutants absorption. Appl. Surf. Sci. 2020, 509, 144818. [CrossRef]

43. Peng, Q.; Li, Y.; He, X.; Gui, X.; Shang, Y.; Wang, C.; Wang, C.; Zhao, W.; Du, S.; Shi, E. Graphene nanoribbon aerogels unzipped from carbon nanotube sponges. Adv. Mater. 2014, 26, 3241-3247. [CrossRef] [PubMed]

44. Zhang, E.; Liu, W.; Liu, X.; Zhao, Z.; Yang, Y. A facile route to prepare nitrogen-doped carbon microspheres/graphene aerogel with high compressibility and superior capacitive property. Mater. Today Commun. 2020, 24, 101125. [CrossRef]

45. Zhang, Z.; Kutana, A.; Yang, Y.; Krainyukova, N.V.; Penev, E.S.; Yakobson, B.I. Nanomechanics of carbon honeycomb cellular structures. Carbon 2017, 113, 26-32. [CrossRef]

46. Jiao, C.; Xiong, J.; Tao, J.; Xu, S.; Zhang, D.; Lin, H.; Chen, Y. Sodium alginate/graphene oxide aerogel with enhanced strengthtoughness and its heavy metal adsorption study. Int. J. Biol. Macromol. 2016, 83, 133-141. [CrossRef] [PubMed]

47. Yu, R.; Shi, Y.; Yang, D.; Liu, Y.; Qu, J.; Yu, Z.-Z. Graphene oxide/chitosan aerogel microspheres with honeycomb-cobweb and radially oriented microchannel structures for broad-spectrum and rapid adsorption of water contaminants. ACS Appl. Mater. Interfaces 2017, 9, 21809-21819. [CrossRef] [PubMed]

48. Liu, Y.; Yang, D.; Shi, Y.; Song, L.; Yu, R.; Qu, J.; Yu, Z.-Z. Silver Phosphate/Graphene Oxide Aerogel Microspheres with Radially Oriented Microchannels for Highly Efficient and Continuous Removal of Pollutants from Wastewaters. ACS Sustain. Chem. Eng. 2019, 7, 11228-11240. [CrossRef] 
49. Afroze, J.D.; Abden, M.J.; Yuan, Z.; Wang, C.; Wei, L.; Chen, Y.; Tong, L. Core-shell structured graphene aerogels with multifunctional mechanical, thermal and electromechanical properties. Carbon 2020, 162, 365-374. [CrossRef]

50. Lv, S.; Ma, Y.; Qiu, C.; Sun, T.; Liu, J.; Zhou, Q. Effect of graphene oxide nanosheets of microstructure and mechanical properties of cement composites. Constr. Build. Mater. 2013, 49, 121-127. [CrossRef]

51. Zhu, C.; Liu, T.; Qian, F.; Han, T.Y.-J.; Duoss, E.B.; Kuntz, J.D.; Spadaccini, C.M.; Worsley, M.A.; Li, Y. Supercapacitors based on three-dimensional hierarchical graphene aerogels with periodic macropores. Nano Lett. 2016, 16, 3448-3456. [CrossRef] [PubMed]

52. Li, P.; Jin, Z.; Peng, L.; Zhao, F.; Xiao, D.; Jin, Y.; Yu, G. Stretchable all-gel-state fiber-shaped supercapacitors enabled by macromolecularly interconnected 3D graphene/nanostructured conductive polymer hydrogels. Adv. Mater. 2018, 30, 1800124. [CrossRef]

53. Lv, S.H.; Zhu, L.L.; Li, Y.; Jia, C.M.; Sun, S.Y. The Adsorption capacity of GONs $/ \mathrm{CMC} / \mathrm{Fe}_{3} \mathrm{O}_{4}$ magnetic composite microspheres and applications for purifying dye wastewater. Materials 2017, 10, 58. [CrossRef] [PubMed]

54. Yagub, M.T.; Sen, T.K.; Afroze, S.; Ang, H.M. Dye and its removal from aqueous solution by adsorption: A review. Adv. Colloid Interface Sci. 2014, 209, 172-184. [CrossRef]

55. Gao, Y.; Chen, K.; Ren, X.; Alsaedi, A.; Hayat, T.; Chen, C. Exploring the aggregation mechanism of graphene oxide in the presence of radioactive elements: Experimental and theoretical studies. Environ. Sci. Technol. 2018, 52, 12208-12215. [CrossRef]

56. Labiadh, L.; Kamali, A.R. 3D graphene nanoedges as efficient dye adsorbents with ultra-high thermal regeneration performance. Appl. Surf. Sci. 2019, 490, 383-394. [CrossRef]

57. Liu, H.; Qiu, H. Recent advances of 3D graphene-based adsorbents for sample preparation of water pollutants: A review. Chem. Eng. J. 2020, 393, 124691. [CrossRef]

58. Hong, J.Y.; Bak, B.M.; Wie, J.J.; Kong, J.; Park, H.S. Reversibly compressible, highly elastic, and durable graphene aerogels for energy storage devices under limiting conditions. Adv. Funct. Mater. 2015, 25, 1053-1062. [CrossRef]

59. Ma, Y.; Yue, Y.; Zhang, H.; Cheng, F.; Zhao, W.; Rao, J.; Luo, S.; Wang, J.; Jiang, X.; Liu, Z. 3D synergistical MXene/reduced graphene oxide aerogel for a piezoresistive sensor. ACS Nano 2018, 12, 3209-3216. [CrossRef] [PubMed]

60. Ha, H.; Shanmuganathan, K.; Ellison, C.J. Mechanically stable thermally crosslinked poly (acrylic acid)/reduced graphene oxide aerogels. ACS Appl. Mater. Interfaces 2015, 7, 6220-6229. [CrossRef] [PubMed]

61. He, X.; Liu, Q.; Zhong, W.; Chen, J.; Sun, D.; Jiang, H.; Liu, K.; Wang, W.; Wang, Y.; Lu, Z.; et al. Strategy of Constructing LightWeight and Highly Compressible Graphene-Based Aerogels with an ordered unique configuration for wearable piezoresistive sensors. ACS Appl. Mater. Interfaces 2019, 11, 19350-19362. [CrossRef]

62. Balandin, A.A.; Ghosh, S.; Bao, W.; Calizo, I.; Teweldebrhan, D.; Miao, F.; Lau, C.N. Superior thermal conductivity of single-layer graphene. Nano Lett. 2008, 8, 902-907. [CrossRef]

63. Zhong, Y.; Zhou, M.; Huang, F.; Lin, T.; Wan, D. Effect of graphene aerogel on thermal behavior of phase change materials for thermal management. Sol. Energy Mater. Sol. Cells 2013, 113, 195-200. [CrossRef]

64. Wang, Z.; Yang, H.; Li, Y.; Zheng, X. Robust Silk Fibroin/Graphene Oxide Aerogel Fiber for Radiative Heating Textiles. ACS Appl. Mater. Interfaces 2020, 12, 15726-15736. [CrossRef] [PubMed]

65. Noroozi, M.; Panahi-Sarmad, M.; Abrisham, M.; Amirkiai, A.; Asghari, N.; Golbaten-Mofrad, H.; Karimpour-Motlagh, N.; Goodarzi, V.; Bahramian, A.R.; Zahiri, B. Nanostructure of Aerogels and Their Applications in Thermal Energy Insulation. ACS Appl. Energy Mater. 2019, 2, 5319-5349. [CrossRef]

66. Chen, J.-H.; Jang, C.; Xiao, S.; Ishigami, M.; Fuhrer, M.S. Intrinsic and extrinsic performance limits of graphene devices on $\mathrm{SiO}_{2}$. Nat. Nanotechnol. 2008, 3, 206. [CrossRef]

67. Song, L.-T.; Wu, Z.-Y.; Liang, H.-W.; Zhou, F.; Yu, Z.-Y.; Xu, L.; Pan, Z.; Yu, S.-H. Macroscopic-scale synthesis of nitrogen-doped carbon nanofiber aerogels by template-directed hydrothermal carbonization of nitrogen-containing carbohydrates. Nano Energy 2016, 19, 117-127. [CrossRef]

68. Song, Z.; Liu, W.; Xiao, P.; Zhao, Z.; Liu, G.; Qiu, J. Nano-iron oxide $\left(\mathrm{Fe}_{2} \mathrm{O}_{3}\right) /$ three-dimensional graphene aerogel composite as supercapacitor electrode materials with extremely wide working potential window. Mater. Lett. 2015, 145, 44-47. [CrossRef]

69. Yun, X.; Li, J.; Chen, X.; Chen, H.; Xiao, L.; Xiang, K.; Chen, W.; Liao, H.; Zhu, Y. Porous $\mathrm{Fe}_{2} \mathrm{O}_{3}$ modified by nitrogen-doped carbon quantum dots/reduced graphene oxide composite aerogel as a high-capacity and high-rate anode material for alkaline aqueous batteries. ACS Appl. Mater. Interfaces 2019, 11, 36970-36984. [CrossRef] [PubMed]

70. Chen, M.; Duan, S.; Zhang, L.; Wang, Z.; Li, C. Three-dimensional porous stretchable and conductive polymer composites based on graphene networks grown by chemical vapour deposition and PEDOT: PSS coating. Chem. Commun. 2015, 51, 3169-3172 [CrossRef] [PubMed]

71. Yue, Y.; Liu, N.; Ma, Y.; Wang, S.; Liu, W.; Luo, C.; Zhang, H.; Cheng, F.; Rao, J.; Hu, X. Highly self-healable 3D microsupercapacitor with MXene-graphene composite aerogel. ACS Nano 2018, 12, 4224-4232. [CrossRef]

72. Shannon, M.A.; Bohn, P.W.; Elimelech, M.; Georgiadis, J.G.; Marinas, B.J.; Mayes, A.M. Science and technology for water purification in the coming decades. Nature 2008, 452, 301-310. [CrossRef]

73. Kim, H.; Kang, S.-O.; Park, S.; Park, H.S. Adsorption isotherms and kinetics of cationic and anionic dyes on three-dimensional reduced graphene oxide macrostructure. J. Ind. Eng. Chem. 2015, 21, 1191-1196. [CrossRef]

74. Zhan, W.; Gao, L.; Fu, X.; Siyal, S.H.; Sui, G.; Yang, X. Green synthesis of amino-functionalized carbon nanotube-graphene hybrid aerogels for high performance heavy metal ions removal. Appl. Surf. Sci. 2019, 467, 1122-1133. [CrossRef] 
75. Mariana, M.; HPS, A.K.; Yahya, E.B.; Olaiya, N.; Alfatah, T.; Suriani, A.; Mohamed, A. Recent trends and future prospects of nanostructured aerogels in water treatment applications. J. Water Process Eng. 2022, 45, 102481. [CrossRef]

76. Wang, L.; Zhu, D.; Duan, L.; Chen, W. Adsorption of single-ringed N-and S-heterocyclic aromatics on carbon nanotubes. Carbon 2010, 48, 3906-3915. [CrossRef]

77. Yang, S.; Shen, C.; Chen, L.; Wang, C.; Rana, M.; Lv, P. Vapor-liquid Deposition Strategy to Prepare Superhydrophobic and Superoleophilic Graphene Aerogel for Oil-Water Separation. ACS Appl. Nano Mater. 2018, 1, 531-540. [CrossRef]

78. Gusain, R.; Kumar, N.; Ray, S.S. Recent advances in carbon nanomaterial-based adsorbents for water purification. Coord. Chem. Rev. 2020, 405, 213111. [CrossRef]

79. Yang, Q.; Lu, R.; Ren, S.; Chen, C.; Chen, Z.; Yang, X. Three dimensional reduced graphene oxide/ZIF-67 aerogel: Effective removal cationic and anionic dyes from water. Chem. Eng. J. 2018, 348, 202-211. [CrossRef]

80. Ye, Y.; Yin, D.; Wang, B.; Zhang, Q. Synthesis of three-dimensional $\mathrm{Fe}_{3} \mathrm{O}_{4}$ /graphene aerogels for the removal of arsenic ions from water. J. Nanomater. 2015, 2015, 864864. [CrossRef]

81. Wu, S.; Zhang, K.; Wang, X.; Jia, Y.; Sun, B.; Luo, T.; Meng, F.; Jin, Z.; Lin, D.; Shen, W. Enhanced adsorption of cadmium ions by 3D sulfonated reduced graphene oxide. Chem. Eng. J. 2015, 262, 1292-1302. [CrossRef]

82. Kabiri, S.; Tran, D.N.; Azari, S.; Losic, D. Graphene-diatom silica aerogels for efficient removal of mercury ions from water. ACS Appl. Mater. Interfaces 2015, 7, 11815-11823. [CrossRef] [PubMed]

83. Liu, J.; Ge, X.; Ye, X.; Wang, G.; Zhang, H.; Zhou, H.; Zhang, Y.; Zhao, H. 3D graphene $/ \delta-\mathrm{MnO}_{2}$ aerogels for highly efficient and reversible removal of heavy metal ions. J. Mater. Chem. A 2016, 4, 1970-1979. [CrossRef]

84. Platero, E.; Fernandez, M.E.; Bonelli, P.R.; Cukierman, A.L. Graphene oxide/alginate beads as adsorbents: Influence of the load and the drying method on their physicochemical-mechanical properties and adsorptive performance. J. Colloid Interface Sci. 2017, 491, 1-12. [CrossRef] [PubMed]

85. Yang, X.; Li, Y.; Du, Q.; Sun, J.; Chen, L.; Hu, S.; Wang, Z.; Xia, Y.; Xia, L. Highly effective removal of basic fuchsin from aqueous solutions by anionic polyacrylamide/graphene oxide aerogels. J. Colloid Interface Sci. 2015, 453, 107-114. [CrossRef]

86. Wu, Z.; Huang, W.; Shan, X.; Li, Z. Preparation of a porous graphene oxide/alkali lignin aerogel composite and its adsorption properties for methylene blue. Int. J. Biol. Macromol. 2020, 143, 325-333. [CrossRef] [PubMed]

87. Xu, J.; Du, P.; Bi, W.; Yao, G.; Li, S.; Liu, H. Graphene oxide aerogels co-functionalized with polydopamine and polyethylenimine for the adsorption of anionic dyes and organic solvents. Chem. Eng. Res. Des. 2020, 154, 192-202. [CrossRef]

88. Zhang, Y.; Li, K.; Liao, J. Facile synthesis of reduced-graphene-oxide/rare-earth-metal-oxide aerogels as a highly efficient adsorbent for Rhodamine-B. Appl. Surf. Sci. 2020, 504, 144377. [CrossRef]

89. Yao, Q.; Fan, B.; Xiong, Y.; Jin, C.; Sun, Q.; Sheng, C. 3D assembly based on 2D structure of cellulose nanofibril/graphene oxide hybrid aerogel for adsorptive removal of antibiotics in water. Sci. Rep. 2017, 7, 45914. [CrossRef] [PubMed]

90. Sun, X.F.; Guo, B.B.; He, L.; Xia, P.F.; Wang, S.G. Electrically accelerated removal of organic pollutants by a three-dimensional graphene aerogel. AIChE J. 2016, 62, 2154-2162. [CrossRef]

91. Chen, Z.; Jin, L.; Hao, W.; Ren, W.; Cheng, H.-M. Synthesis and applications of three-dimensional graphene network structures. Mater. Today 2019, 5, 100027. [CrossRef]

92. Wei, N.; Wang, Q.; Ma, Y.; Ruan, L.; Zeng, W.; Liang, D.; Xu, C.; Huang, L.; Zhao, J. Superelastic active graphene aerogels dried in natural environment for sensitive supercapacitor-type stress sensor. Electrochim. Acta 2018, 283, 1390-1400. [CrossRef]

93. Wang, M.; Duan, X.; Xu, Y.; Duan, X. Functional three-dimensional graphene/polymer composites. ACS Nano 2016, 10, 7231-7247. [CrossRef] [PubMed]

94. Zhao, J.; Pan, R.; Sun, R.; Wen, C.; Zhang, S.-L.; Wu, B.; Nyholm, L.; Zhang, Z.-B. High-conductivity reduced-grapheneoxide/copper aerogel for energy storage. Nano Energy 2019, 60, 760-767. [CrossRef]

95. Wu, Z.S.; Winter, A.; Chen, L.; Sun, Y.; Turchanin, A.; Feng, X.; Müllen, K. Three-dimensional nitrogen and boron co-doped graphene for high-performance all-solid-state supercapacitors. Adv. Mater. 2012, 24, 5130-5135. [CrossRef] [PubMed]

96. Wang, H.; Li, R.; Li, M.; Li, Z. Flower-like $\mathrm{Fe}_{2} \mathrm{O}_{3} @$ multiple graphene aerogel for high-performance supercapacitors. J. Alloys Compd. 2018, 742, 759-768. [CrossRef]

97. Xu, L.; Wang, S.; Zhang, X.; He, T.; Lu, F.; Li, H.; Ye, J. A facile method of preparing $\mathrm{LiMnPO}_{4} /$ reduced graphene oxide aerogel as cathodic material for aqueous lithium-ion hybrid supercapacitors. Appl. Surf. Sci. 2018, 428, 977-985. [CrossRef]

98. Sun, R.; Chen, H.; Li, Q.; Song, Q.; Zhang, X. Spontaneous assembly of strong and conductive graphene/polypyrrole hybrid aerogels for energy storage. Nanoscale 2014, 6, 12912-12920. [CrossRef]

99. Zhou, Y.; Hu, X.; Guo, S.; Yu, C.; Zhong, S.; Liu, X. Multi-functional graphene/carbon nanotube aerogels for its applications in supercapacitor and direct methanol fuel cell. Electrochim. Acta 2018, 264, 12-19. [CrossRef]

100. Wei, X.; Wan, S.; Gao, S. Self-assembly-template engineering nitrogen-doped carbon aerogels for high-rate supercapacitors. Nano Energy 2016, 28, 206-215. [CrossRef]

101. Tingting, Y.; Ruiyi, L.; Xiaohuan, L.; Zaijun, L.; Zhiguo, G.; Guangli, W.; Junkang, L. Nitrogen and sulphur-functionalized multiple graphene aerogel for supercapacitors with excellent electrochemical performance. Electrochim. Acta 2016, 187, 143-152. [CrossRef]

102. Kim, D.W.; Jung, S.M.; Jung, H.Y. Long term thermostable supercapacitor using in-situ $\mathrm{SnO}_{2}$ doped porous graphene aerogel. J. Power Sources 2020, 448, 227422. [CrossRef]

103. Tian, W.; Cheng, D.; Wang, S.; Xiong, C.; Yang, Q. Phytic acid modified manganese dioxide/graphene composite aerogel as high-performance electrode materials for supercapacitors. Appl. Surf. Sci. 2019, 495, 143589. [CrossRef] 
104. Liu, Z.; Lyu, J.; Fang, D.; Zhang, X. Nanofibrous Kevlar aerogel threads for thermal insulation in harsh environments. ACS Nano 2019, 13, 5703-5711. [CrossRef]

105. Wang, Y.-T.; Liao, S.-F.; Shang, K.; Chen, M.-J.; Huang, J.-Q.; Wang, Y.-Z.; Schiraldi, D.A. Efficient approach to improving the flame retardancy of poly (vinyl alcohol)/clay aerogels: Incorporating piperazine-modified ammonium polyphosphate. ACS Appl. Mater. Interfaces 2015, 7, 1780-1786. [CrossRef] [PubMed]

106. Cai, H.; Sharma, S.; Liu, W.; Mu, W.; Liu, W.; Zhang, X.; Deng, Y. Aerogel microspheres from natural cellulose nanofibrils and their application as cell culture scaffold. Biomacromolecules 2014, 15, 2540-2547. [CrossRef]

107. Chen, H.-B.; Chiou, B.-S.; Wang, Y.-Z.; Schiraldi, D.A. Biodegradable pectin/clay aerogels. ACS Appl. Mater. Interfaces 2013, 5 , 1715-1721. [CrossRef] [PubMed]

108. Yue, C.; Feng, J.; Feng, J.; Jiang, Y. Ultralow-density and high-strength graphene aerogels composites for thermal insulation. Mater. Lett. 2017, 188, 169-171. [CrossRef]

109. Wang, Z.; Wei, R.; Gu, J.; Liu, H.; Liu, C.; Luo, C.; Kong, J.; Shao, Q.; Wang, N.; Guo, Z. Ultralight, highly compressible and fire-retardant graphene aerogel with self-adjustable electromagnetic wave absorption. Carbon 2018, 139, 1126-1135. [CrossRef]

110. Zhang, Q.; Lin, D.; Deng, B.; Xu, X.; Nian, Q.; Jin, S.; Leedy, K.D.; Li, H.; Cheng, G.J. Flyweight, superelastic, electrically conductive, and flame-retardant 3D multi-nanolayer graphene/ceramic metamaterial. Adv. Mater. 2017, 29, 1605506. [CrossRef] [PubMed]

111. Maleki, H.; Durães, L.; García-González, C.A.; del Gaudio, P.; Portugal, A.; Mahmoudi, M. Synthesis and biomedical applications of aerogels: Possibilities and challenges. Adv. Colloid Interface Sci. 2016, 236, 1-27. [CrossRef] [PubMed]

112. Zhang, B.; Wang, Y.; Zhai, G. Biomedical applications of the graphene-based materials. Mater. Sci. Eng. C 2016, 61, 953-964. [CrossRef]

113. Liu, S.; Zhou, C.; Mou, S.; Li, J.; Zhou, M.; Zeng, Y.; Luo, C.; Sun, J.; Wang, Z.; Xu, W. Biocompatible graphene oxide-collagen composite aerogel for enhanced stiffness and in situ bone regeneration. Mater. Sci. Eng. C 2019, 105, 110137. [CrossRef] [PubMed]

114. Ayazi, H.; Akhavan, O.; Raoufi, M.; Varshochian, R.; Motlagh, N.S.H.; Atyabi, F. Graphene aerogel nanoparticles for in-situ loading/pH sensitive releasing anticancer drugs. Colloids Surf. B 2020, 186, 110712. [CrossRef]

115. Luo, J.; Lai, J.; Zhang, N.; Liu, Y.; Liu, R.; Liu, X. Tannic acid induced self-assembly of three-dimensional graphene with good adsorption and antibacterial properties. ACS Sustain. Chem. Eng. 2016, 4, 1404-1413. [CrossRef]

116. McCallion, C.; Burthem, J.; Rees-Unwin, K.; Golovanov, A.; Pluen, A. Graphene in therapeutics delivery: Problems, solutions and future opportunities. Eur. J. Pharm. Biopharm. 2016, 104, 235-250. [CrossRef]

117. López-Dolado, E.; González-Mayorga, A.; Portolés, M.T.; Feito, M.J.; Ferrer, M.L.; Del Monte, F.; Gutiérrez, M.C.; Serrano, M.C. Subacute tissue response to 3D graphene oxide scaffolds implanted in the injured rat spinal cord. Adv. Healthc. Mater. 2015, 4, 1861-1868. [CrossRef]

118. Zheng, Q.; Lee, J.-h.; Shen, X.; Chen, X.; Kim, J.-K. Graphene-based wearable piezoresistive physical sensors. Mater. Today 2020, 36, 158-179. [CrossRef]

119. Ma, Y.; Zhao, M.; Cai, B.; Wang, W.; Ye, Z.; Huang, J. 3D graphene foams decorated by CuO nanoflowers for ultrasensitive ascorbic acid detection. Biosen. Bioelectron. 2014, 59, 384-388. [CrossRef]

120. Dong, X.; Wang, X.; Wang, L.; Song, H.; Zhang, H.; Huang, W.; Chen, P. 3D graphene foam as a monolithic and macroporous carbon electrode for electrochemical sensing. ACS Appl. Mater. Interfaces 2012, 4, 3129-3133. [CrossRef]

121. Sun, Y.; Lin, Y.; Sun, W.; Han, R.; Luo, C.; Wang, X.; Wei, Q. A highly selective and sensitive detection of insulin with chemiluminescence biosensor based on aptamer and oligonucleotide-AuNPs functionalized nanosilica@ graphene oxide aerogel. Anal. Chim. Acta 2019, 1089, 152-164. [CrossRef] [PubMed] 